\title{
HISTOLOGICAL VARIATION IN OSTEODERMS PANOCHTHUS SP. AND GLYPTOTHERIUM SP. (XENARTHRA: MAMMALIA) FROM THE BRAZILIAN INTERTROPICAL REGION
}

\author{
SHALINE ELAIDE DE ARAÚJO \\ Programa de Pós-Graduação em Ciências Naturais, Universidade do Estado do Rio Grande do Norte, \\ Av. Professor Antônio Campos, s/n, 59610-090, Mossoró, RN, Brazil. \\ KLEBERSON DE OLIVEIRA PORPINO \\ Departamento de Ciências Biológicas, Universidade do Estado do Rio Grande do Norte, \\ Av. Professor Antônio Campos, s/n, 59610-090, Mossoró, RN, Brazil.
}

\begin{abstract}
Glyptodonts are one of the most peculiar mammal groups that inhabited South America during the Pleistocene. Among the main characteristics of the group is the presence of a carapace composed of hundreds of osteoderms, which take on variable forms and external ornamentation. The fossiliferous sites of the Brazilian Intertropical Region (RIB) are rich in glyptodont fossils, of which the osteoderms are the most registered elements, possibly due to their high potential for preservation. Recently, the analysis of histological characteristics has proven useful in the differentiation of genera and species. However, the samples used are still limited and do not consider possible differences among different regions of the carapace. In this work, we evaluate possible histological variations among the osteoderms of Glyptotherium sp. and Panochthus sp. from different regions of the carapace and, based on a larger number of specimens, discuss their implications for the systematics of these genera. We found differences among osteoderms from distinct regions of the carapace for both analysed genera. Within the morphological variation described for the osteoderms of Glyptotherium sp., it is observed that they have more characteristics in common with the species Glyptotherium floridanum than with Glyptodon reticulatus, thus reinforcing that the Glyptodontinae findings in the BIR belong to the genus Glyptotherium sp. The osteoderms of Panochthus share a central region with common characters regardless of the position they occupy in the carapace; the main histological differences among them reside in the layers of compact bone, which show differences even in osteoderms of the same region. Caution is required when the presence of Neuryurus in the RIB deposits based on osteoderms is proposed, as morphological and histological characteristics of some representative of this genus overlap with some altered osteoderms (likely pathological) of the Panochthus sp. studied here.
\end{abstract}

Keywords: osteoderms, variation, carapace, Glyptotherium, Panochthus.

RESUMO - Os gliptodontes são considerados um dos grupos de mamíferos mais peculiares que habitaram a América do Sul durante o Pleistoceno. Entre as principais características do grupo está a presença de uma carapaça constituída de centenas de osteodermos fusionados (exceto nos indivíduos mais juvenis), os quais apresentam formatos e ornamentação externa variados. Os depósitos fossilíferos presentes na Região Intertropical Brasileira (RIB) são ricos em ocorrências de gliptodontes e os osteodermos são os elementos mais registrados, possivelmente devido ao seu alto potencial de preservação. Recentemente, a análise de características histológicas que podem ser usadas para diferenciar os gêneros ou espécies vem sendo exploradas em alguns estudos sobre o grupo. Entretanto, a amostragem utilizada ainda é limitada e não contempla possíveis diferenças entre regiões diferentes da carapaça. Dessa forma, o objetivo desse trabalho foi avaliar possíveis diferenças entre osteodermos de diferentes regiões da carapaça de Glyptotherium sp. e Panochthus sp. comparando os gêneros estudados com outros já descritos baseando-se em um maior número de exemplares e discutir suas implicações na sistemática do grupo. De acordo com os resultados obtidos existem diferenças quando comparamos osteodermos de regiões distintas da carapaça de Glyptotherium sp. e Panochthus sp. Dentro da variação morfológica observada para os osteodermos de Glyptotherium sp. constata-se que esses possuem mais características em comum com a espécie Glyptotherium floridanum do que com Glyptodon reticulatus, reforçando assim que os achados de Glyptodontinae presentes na RIB pertencem ao gênero Glyptotherium sp. É necessário cautela ao se propor a presença de Neuryurus nos depósitos da RIB com base em osteodermos, uma vez que foi constatada sobreposição de características morfológicas e histológicas de alguns representantes deste gênero com os osteodermos alterados de Panochthus sp. aqui estudados.

Palavras-chave: osteodermos, variação, carapaça, Glyptotherium, Panochthus. 


\section{INTRODUCTION}

Glyptodonts are one the most peculiar mammalian groups that inhabited South America during the Cenozoic. One of the main characteristics of the group is the presence of a carapace without transverse mobile bands, in contrast to other cingulates, such as dasypodids and pampatheres, formed by fused, thick osteoderms (except in immature individuals; Gillete et al., 2016), which present distinct shapes and external ornamentation patterns that are diagnostic for both genera and species (Paula-Couto, 1979; Gillette et al., 2016). They diverged from other cingulates approximately 35 million years ago according to modern estimates (Fariña et al., 2013; Delsuc et al., 2016).

Remains of glyptodonts are very common in the fossiliferous sites of the Brazilian Intertropical Region (BIR), where they are represented mostly by osteoderms. This is arguably a result of the osteoderms' high preservation potential due to the great number that can be produced from a single individual (Gaudin \& Wible, 2006; Pereira et al., 2014). Among the glyptodont genera most common in the BIR are Panochthus sp. (Panochthinae) and Glyptotherium sp. (Glyptodontinae) (Oliveira et al., 2010; Porpino et al., 2014).

The first species of Panochthus described from the BIR was Panochthus greslebini, based on a caudal tube collected from a tank deposit in the Jaguaretama municipality, Ceará State (Castellanos, 1942; Porpino et al., 2014). Later, another species of this genus - Panochthus jaguaribensis - was also established based on a caudal tube from Limoeiro do Norte municipality, Ceará State (Moreira, 1965; Porpino et al., 2014). In addition to these, a fair amount of isolated osteoderms and carapace fragments, as well as some postcranial material, have been assigned to these species (e.g. Moreira, 1971; Porpino \& Bergqvist, 2002). However, there are doubts concerning some specific attributions of these elements, given that the caudal tube is the only element known so far that bears diagnostic characters for both species (Porpino et al., 2014). Consequently, Porpino et al. (2014) suggested that all material from Panochthus found in the BIR, including osteoderms, should be assigned to Panochthus sp. unless a clear association with caudal tubes with preserved diagnostic characters can be established.

Past records of Glyptodontinae in the BIR (chiefly of isolated osteoderms) were assigned to Glyptodon, a genus very common in the Pleistocene deposits of southern Brazil. However, Oliveira et al. (2010) suggested that at least part of these records likely belong to the North American genus Glyptotherium, which despite possessing osteoderms similar to Glyptodon - its sister genus (Zurita et al., 2013) - differs from the latter genus in that it has rougher external surfaces, shallower main and radial sulci and peripheral figures ranging from eight to nine.

In addition to being a traditional source of macroscopic characters for specific differentiation, isolated osteoderms and carapace fragments have recently been used as sources for mitochondrial DNA for use in molecular phylogenetic analyses (e.g. Delsuc et al., 2016), for histological characters useful in systematics, and also to infer ontogenetic and functional aspects of the animal (Hill, 2006; Wolf et al., 2012; Pereira et al., 2014).

Until now, all histological studies on glyptodont osteoderms relied on a few specimens and did not take into account potential differences across the carapace, even though glyptodont carapaces can have hundreds of osteoderms of which can bear distinctive macroscopic features (e.g. relative size of main figures) due to where they formed (see for instance Gillete et al., 2016). Therefore, the aim of this paper is to evaluate possible histological differences between osteoderms from distinct regions of the carapace for the genera Panochthus and Glyptotherium collected in the BIR, comparing them with other specimens described in the literature and discussing their implications for use in systematics.

\section{MATERIAL AND METHODS}

\section{Material analysed}

We analysed 18 osteoderms housed in Museu Câmara Cascudo (MCC), Natal City, Brazil. They include eight osteoderms assigned to Glyptotherium (four from the dorsal region, two from the lateral region, and two from the region near the posterior border of the carapace) and 10 assigned to Panochthus (one dorsal, four from lateral regions and five bearing ante mortem alterations, including one from the posterior border of the carapace).

The osteoderms of Glyptotherium were collected at the Lajedo da Escada site (5 $\left.5^{\circ} 14^{\prime} 31^{\prime \prime} \mathrm{S}, 37^{\circ} 44^{\prime} 20^{\prime \prime} \mathrm{W}\right)$, Baraúna municipality, Rio Grande do Norte State (Figure 1). It consists of a karst deposit within an outcrop of the Jandaíra Formation, which occupies an area of nearly $5 \mathrm{~km}^{2}$. This outcrop encompasses two karstic pavements separated from each other by a distance of $200 \mathrm{~m}$ (Carvalho et al., 1966). The mammalian fossil fauna of Lajedo da Escada includes small to medium sized taxa, such as Proechimys sp. and Pachyarmatherium, as well as several large sized species, such as Eremotherium laurillardi, Smilodon populator and Notiomastodon waringi (Porpino et al., 2009; AraújoJúnior et al., 2011). In this context, the osteoderms of Glyptotherium described here were found in association with postcranial bones that likely belong to a single individual (Barbosa et al., 2014).

The osteoderms of Panochthus sp. in turn were collected in a tank deposit in Lagoa do Santo site $\left(06^{\circ} 15^{\prime} 39^{\prime \prime}\right.$, $\left.36^{\circ} 31^{\prime} 04^{\prime \prime} \mathrm{W}\right)$, Currais Novos municipality, Rio Grande do Norte State (Figure 1). Until now, there has been little information obtained concerning this deposit, but its vertebrate fauna includes typical Pleistocene megafauna such as Glyptotherium, Eremotherium, Toxodon, Panochthus, Palaeolama and Xenorhinotherium (Araújo-Júnior et al., 2011). This faunal composition is comparable to other tank deposits from Northeastern Brazil (Araújo-Júnior et al., 2011). According to recent studies, the estimated age for such deposits is Late Pleistocene-early Holocene (Araújo-Júnior et al., 2013; França et al., 2014). The osteoderms from Panochthus sp. from the Lagoa do Santo site here described were found in association with a partial carapace (MCC 1603V; Oliveira 


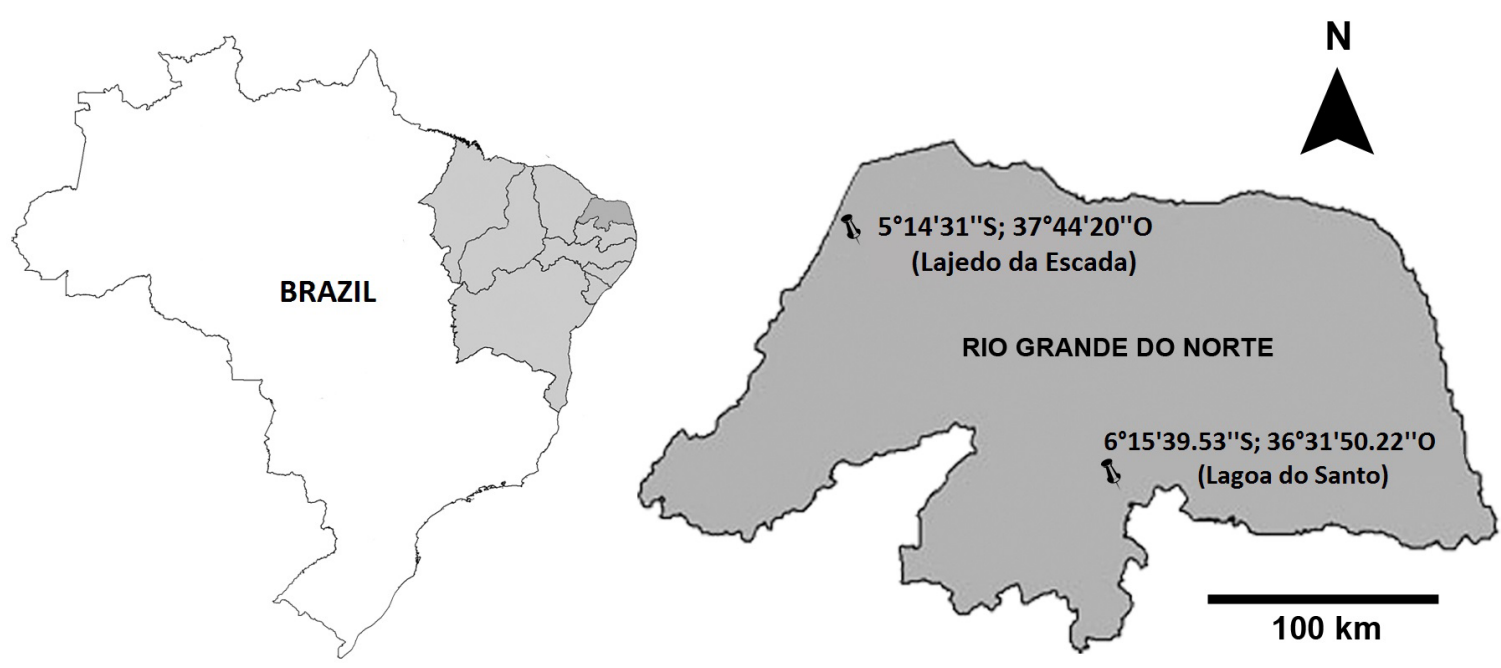

Figure 1. Location map of the Lajedo da Escada and Lagoa do Santo (Rio Grande do Norte, Brazil) fossiliferous sites.

et al., 1984) and few postcranial bones (Porpino \& Bergqvist, 2002), and similar to the material of Glyptotherium mentioned above, may belong to a single individual.

\section{Terminology and systematics}

The taxonomic identification and systematics of the osteoderms here analysed follows Fernicola (2008), Oliveira et al. (2010) and Porpino et al. (2014). Concerning the regions of the carapace from which the isolated osteoderms studied here were derived, we follow Porpino et al. (2014) and Gillette et al. (2016) for Panochthus and Glyptotherium, respectively.

The different sections of the carapace's dorsal region, as defined by Porpino et al. (2014), are anterodorsal, mid-dorsal and posterodorsal; the lateral region, in turn, is divided into anterolateral, mid-lateral and posterolateral. Finally, there are the anterior, lateral and posterior borders. While the osteoderms originating from the lateral and dorsal regions for both Panochthus and Glyptotherium can be differentiated by their shape, it is difficult to assign isolated osteoderms from the dorsal and lateral regions to specific sections, particularly for Panochthus, where the external ornamentation of most osteoderms is indistinctly composed of small polygonal figures. The exceptions are the osteoderms from the lateral region closer to the lateral border and the osteoderms from the posterior border, which bear a main figure. In contrast, the variation in the external ornamentation of osteoderms from the dorsal region of Glyptotherium (see Gillette et al., 2016) sometimes allow for easier identification of the section from which they belong.

According to Oliveira et al. (2010), the osteoderms of Glyptotherium are characterized by rough surfaces, perforated by several small foramina, with shallow main and radial sulci (compared to Glyptodon) and eight to nine peripheral figures around a flat main figure (Figure 2A). However, we follow these authors in restricting our assignment to the generic level, as a specific identification would demand a more extensive revision of the material described so far, an aim well beyond the scope of the present paper.

With regard to Panochthus, Porpino et al. (2014) denominate the small polygonal figures present in osteoderms as small, when not associated with a main figure, and peripheral when associated with them (e.g. osteoderms located close to the lateral border of the carapace; Figure 2B). As mentioned earlier, in addition to osteoderms from the dorsal and lateral regions, we also described osteoderms that bear probable signs of pathological alteration (see discussion); these specimens do not exhibit the characteristic external ornamentation pattern of Panochthus or show residues of it but were found in association with the remaining osteoderms and the partial carapace of this genus (see above). The inclusion of these specimens was motivated by their similarity with some material assigned to Neuryurus in previous works (especially Zurita \& Ferrero, 2009) and with the carapace material of Panochthus showing pathological alteration described by Barbosa \& Luna (2014).

For the histological description of the osteoderms, we follow the terminology employed by Hill (2006), Wolf et al. (2012) and Pereira et al. (2014). All of these studies agree that the cingulate osteoderms present a general "diplöe-like" structure, which consists of a central region of trabecular bone positioned between a superficial and a deep layer of compact bone (Figure 2C).

\section{Preparation of the histological sections}

The paleohistological thin sections analysed in this study were prepared in the Laboratório Geológico de Processamento de Amostras da Faculdade de Geologia da Universidade do Estado do Rio de Janeiro (UERJ). Initially, the osteoderms were sectioned along their sagittal plane 
A

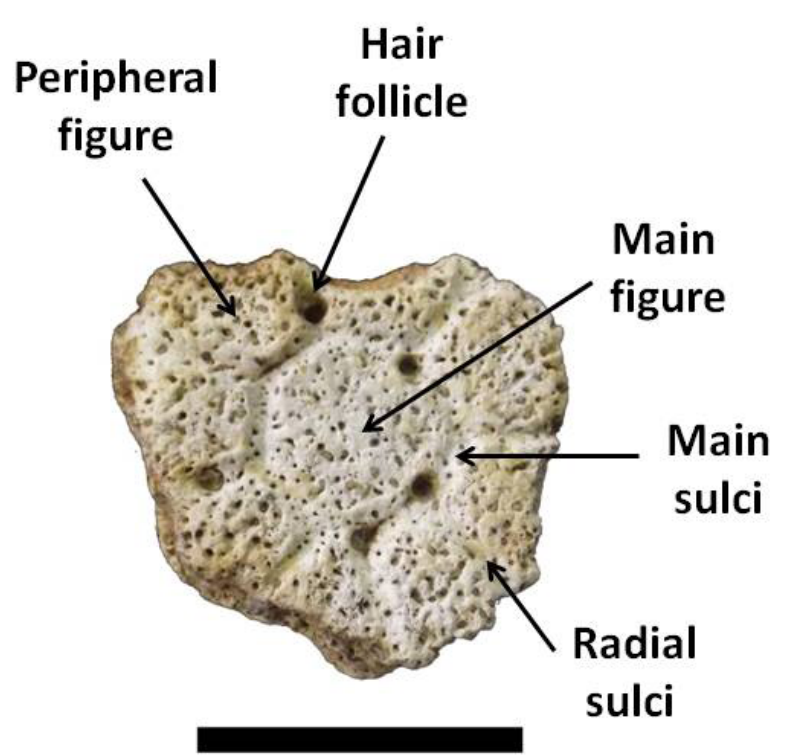

B

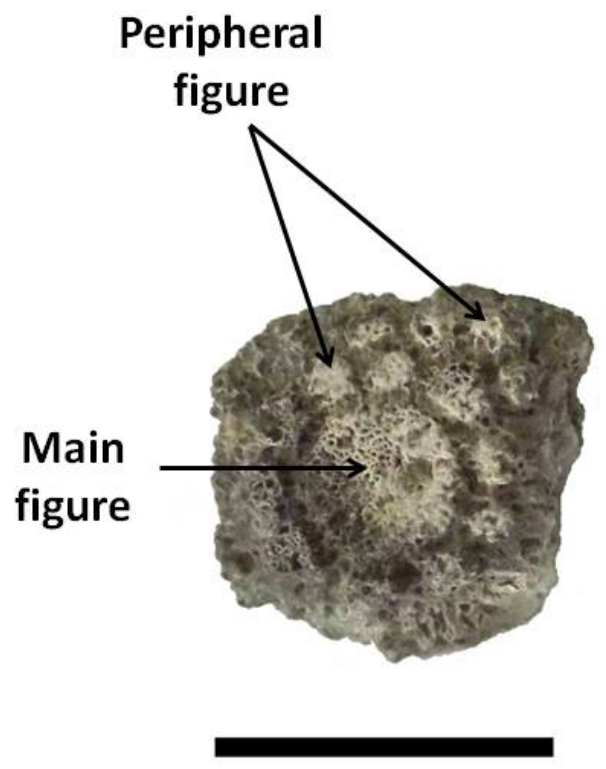

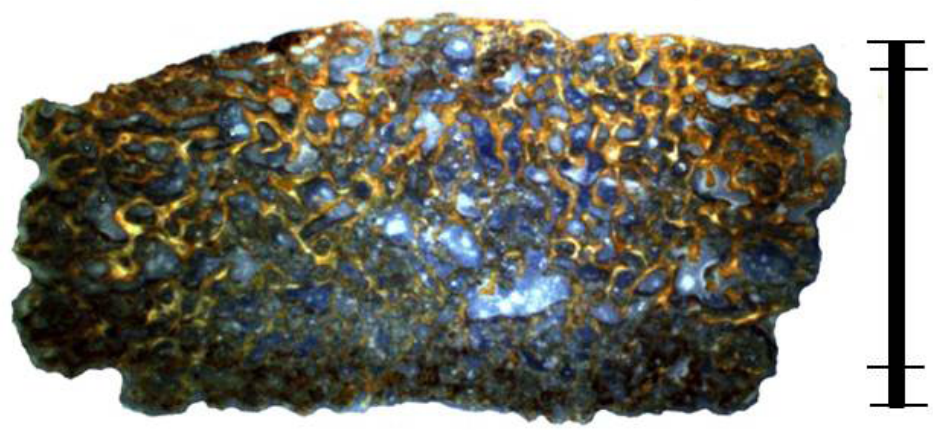

Superficial layer

\author{
Central region
}

Deep layer

Figure 2. Terminology used for the osteoderms of Glyptotherium sp. osteoderms (A); Panochthus sp. $(\mathbf{B})$ and histological terminology $(\mathbf{C})$. Scale bars: A = $40 \mathrm{~mm} ; \mathrm{B}=30 \mathrm{~mm} ; \mathrm{C}=20 \mathrm{~mm}$.

with a diamond cut-off saw, and then the sections obtained were imbedded in epoxy resin, with hardener HY951 in a 10:1 mL proportion to provide consistency and to prevent fractures. Then, the specimens were dried for $24 \mathrm{~h}$. After the drying, the blocks formed by the osteoderms sections embedded into the resin were sectioned again to attain the proper size to be included in glass slides, where they were polished in 320 to 600 grit carbide sandpaper until attaining the ideal thickness for visualization under an optic microscope. The thin sections were examined using a petrographic microscope.

\section{SYSTEMATIC PALAEONTOLOGY}

Suborder GLYPTODONTIA Ameghino, 1889 Superfamily GLYPTODONTOIDEA Gray, 1869

Family GLYPTODONTIDAE Gray, 1869

Subfamily GLYPTODONTINAE Gray, 1869

Glyptotherium Osborn, 1903

Glyptotherium sp.

(Figures 3-8) 
Material analysed. Osteoderms: MCC 1234-V, MCC 2601V, MCC 2579-V, MCC 2092-V, MCC 2593-V, MCC 2096-V, MCC 2328-V and MCC 2585-V.

Osteoderms from the mid-dorsal section (dorsal region) of the carapace. Referred material: MCC 1234-V (length $=53.1$ $\mathrm{mm}$; width $=22.12 \mathrm{~mm}$; thickness $=23.5 \mathrm{~mm})$, MCC $2601-\mathrm{V}$ $(57.94 \times 43.18 \times 21.77 \mathrm{~mm})$, MCC $2579-\mathrm{V}(72.66 \times 49.05 \times$ $19.56 \mathrm{~mm})$ and MCC $2092-\mathrm{V}(50.94 \times 46.05 \times 21.14 \mathrm{~mm})$.

Morphological description. The osteoderms are pentagonal to nearly hexagonal, with a very rough external surface, and a circular main figure surrounded by seven to eight peripheral figures; three to five hair follicle pits are observed in the confluence of the main and radial sulci (Figures 3A, C, E and $G)$. Their internal surface is smooth, flat to gently convex, with zero to three small neurovascular foramina (Figures $3 \mathrm{~B}, \mathrm{D}, \mathrm{F}$ and $\mathrm{H}$ ). The specimen MCC $2579-\mathrm{V}$ shows some small signs of bone remodelling; its main figure is poorly delimited, the sulci are barely visible and there is extensive erosion on nearly $1 / 3$ of its internal surface, where the trabecular tissue is exposed.

Histological description. Overall, the osteoderms show parallel fibre bundles in the deep layer, although in some points, small sets of fibres without clear orientation are observed as well as osteocytes and primary osteons (Figures $4 \mathrm{~A}$ and $\mathrm{B})$. Towards the central region of trabecular bone, there are resorptions areas filled with iron oxide (Figures $4 \mathrm{C}$ and D), which occupy this entire region and stretch until the lower limits of the superficial layer of compact bone. In addition, this central region also presents some primary and secondary osteons (Figures 4E and F). Near the superficial layer of compact bone, fibre bundles with varied orientations appear; at some points, these fibres have a somewhat oblique orientation. The superficial layer of compact bone shows several osteocites and fibre bundles, most of which are oriented parallel to the external surface (Figures $4 \mathrm{G}$ and $\mathrm{H}$ ); some primary and secondary osteons, as well as a few resorption areas, are also present.

Osteoderms from the lateral region. Referred material: MCC $2593-\mathrm{V}(42.37 \times 36.83 \times 19.24 \mathrm{~mm})$ and MCC $2096-\mathrm{V}$ $(55.59 \times 46.54 \times 22.28 \mathrm{~mm})$.

Morphological description. The osteoderms of the lateral region differ from the dorsal region in that they have a more hexagonal-rectangular to clearly rectangular shape (Figures $5 \mathrm{~A}$ and $\mathrm{C}$ ). Their external surfaces have small foramina and a rough aspect, like in the dorsal osteoderms, a well-delimited central figure surrounded by eight to nine peripheral ones,
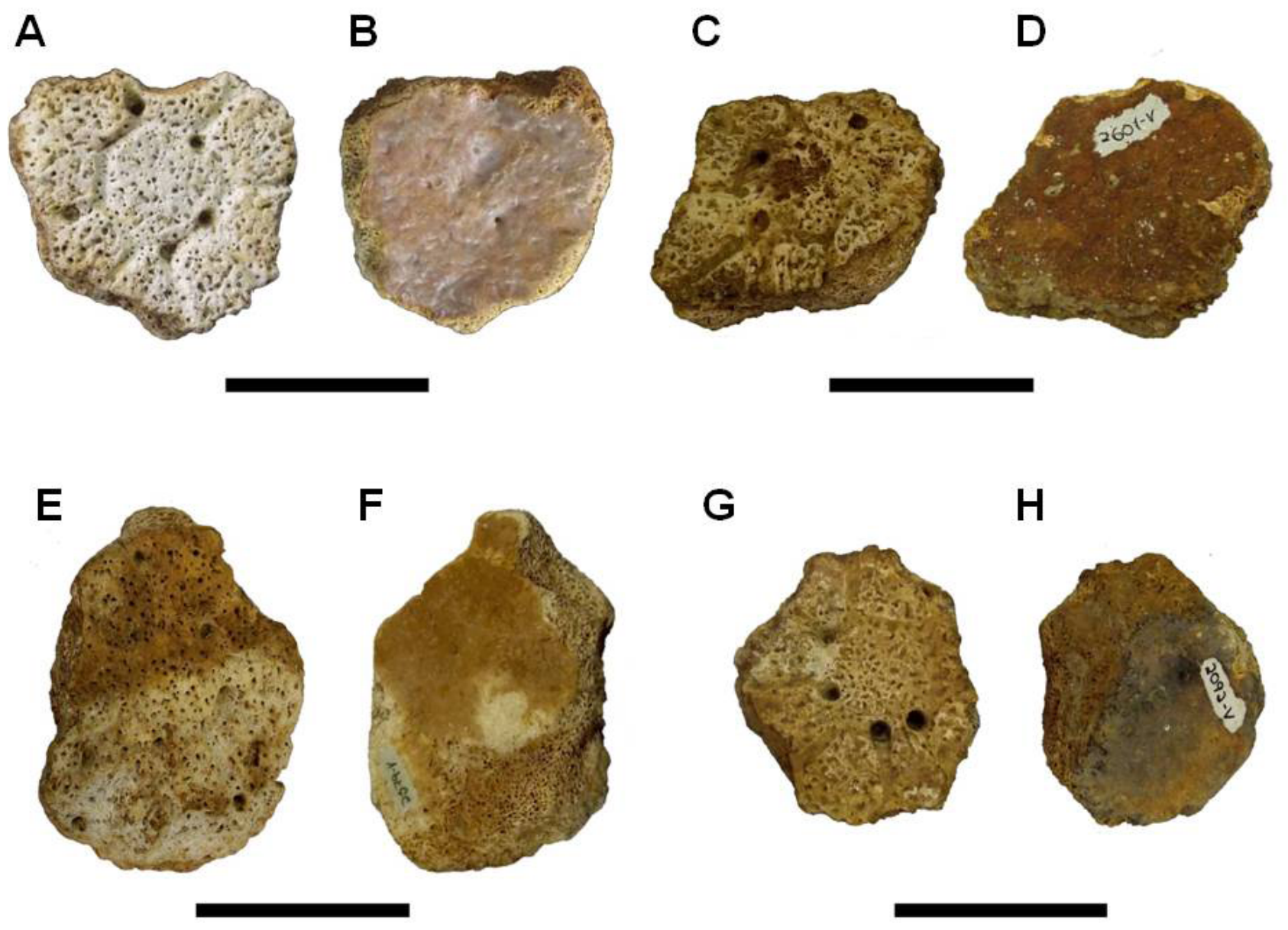

Figure 3. Osteoderms from the dorsal region of Glyptotherium $\mathrm{sp} .: \mathrm{MCC} 1234-\mathrm{V}$ in external (A) and in internal (B) views; MCC 2601-V in external (C) and in internal (D) views; MCC 2579-V in external (E) and internal (F) views; MCC 2092-V in external $(\mathbf{G})$ and internal $(\mathbf{H})$ views. Scale bars $=40 \mathrm{~mm}$. 

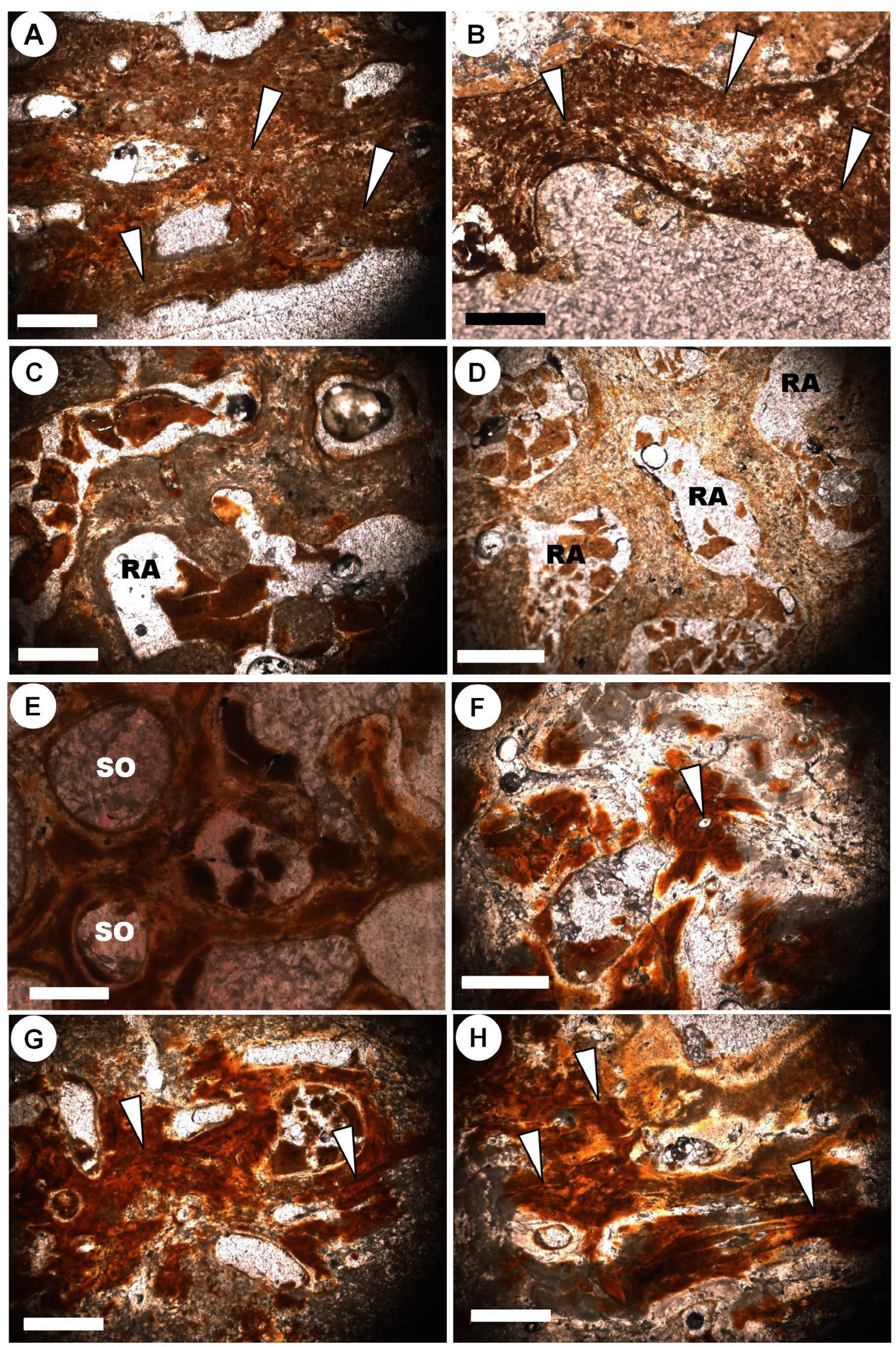

Figure 4. Histological sections of osteoderms from the dorsal region of Glyptotherium sp.: A, fibre bundles aligned parallel to the deep layer of compact bone on MCC 1234-V (white arrows); B, fibre bundles aligned parallel to the deep layer of compact bone in MCC 2579-V; $\mathbf{C}$, resorption area in the central region of MCC 2601-V; D, resorption areas in the central region of MCC 1234-V; E, secondary osteons in the central region of MCC 2579-V; $\mathbf{F}$, primary osteon in the compact surface layer of MCC 2601-V (white arrow); G, fibre bundles aligned parallel to the compact surface layer of MCC 1234-V (white arrows) and (H) osteoderm MCC 2579-V (white arrows). Abbreviations: RA, reabsorption area; SO, secondary osteon. Scale bars $=200 \mu \mathrm{m}$. 
A
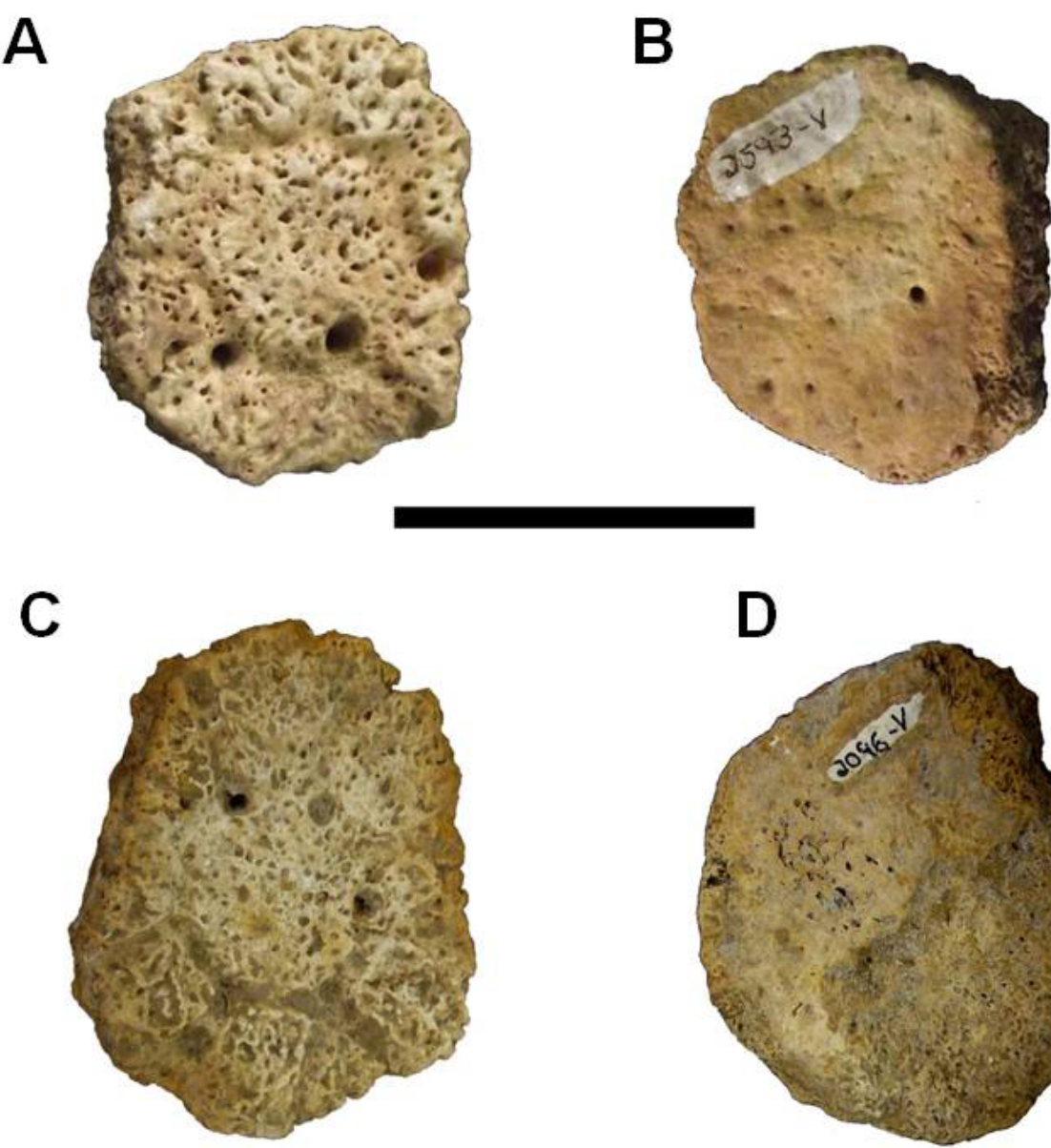

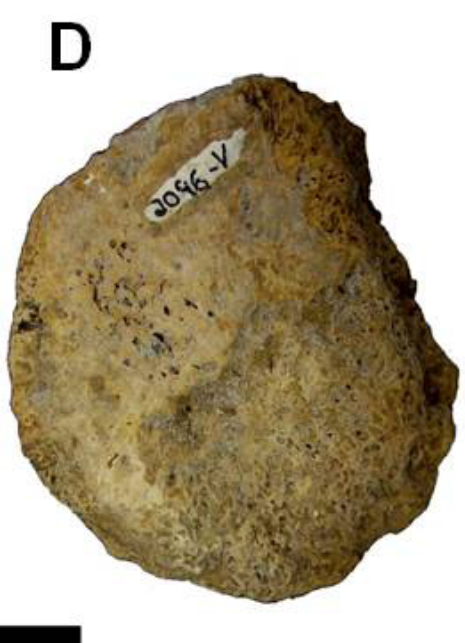

Figure 5. Osteoderms from the lateral region of Glyptotherium sp.: MCC 2593-V in external (A) and in internal (B) views; MCC 2096-V in external (C) and in internal (D) views. Scale bars: A-B $=30 \mathrm{~mm} ; \mathrm{C}-\mathrm{D}=4 \mathrm{~cm}$.

and three hair follicle pits at the intersection of the main and radial sulci. Their internal surface is smooth to gently convex, with up to nine neurovascular foramina (Figure 5B), although they may be absent (Figure 5D). The specimen MCC 2096-V has an eroded area that occupies nearly half of the internal surface where the trabecular bone is exposed.

Histological description. The deep layer of compact bone has fibre bundles, most of which have an orientation parallel to the external surface; in this layer, there are several osteocytes and primary and secondary osteons randomly distributed (Figures $6 \mathrm{~A}$ and $\mathrm{B})$. The central region shows several resorption areas, osteocytes and secondary osteons (Figures $6 \mathrm{C}$ and D). The superficial layer of compact bone, in most cases, presents obliquely oriented fibre bundles, but some have a parallel orientation; some osteocytes, in addition to primary and secondary osteons, are present in this layer (Figures 6E and F). Osteoderms of the posterodorsal section near the posterior border of the carapace. Referred material: MCC $2328-\mathrm{V}$ $(50.50 \times 45.31 \times 36.48 \mathrm{~mm})$ and MCC $2585-\mathrm{V}(44.80 \times$ $41.17 \times 37.97 \mathrm{~mm})$.

Morphological description. These osteoderms differ from those in the lateral and mid-dorsal section in that they are pentagonal and have an external surface without discernible figures. In addition, there is a well-marked depression at the centre of their external surface, which is strongly perforated by foramina and very rough (Figures 7A and C). In one of the lateral borders of specimen MCC $2585-\mathrm{V}$, there is a well-developed hair follicle pit filled with sediment (Figure 7C). The internal surface varies from smooth to slightly convex, or slightly concave in some points in specimen MCC 2585-V (Figures 7B and D), and there are two to nine neurovascular foramina.

Histological description: The superficial compact bone layer bears fibre bundles with mostly oblique orientations, although some regions present varied orientations (Figures $8 \mathrm{~A}$ and $\mathrm{B}$ ), as well as several osteocytes, some primary osteons and resorption areas. In the central region, resorption areas are abundant, showing the long axis in the sagittal plane, and most filled with iron oxide; there are some osteocytes and secondary osteons in this region as well (Figures $8 \mathrm{C}$ and D). The superficial layer of compact bone shows fibre bundles oriented obliquely (Figures $8 \mathrm{E}$ and F), although in some places they are oriented parallel to the external surface; osteocytes and secondary osteons are scarce in this layer. 

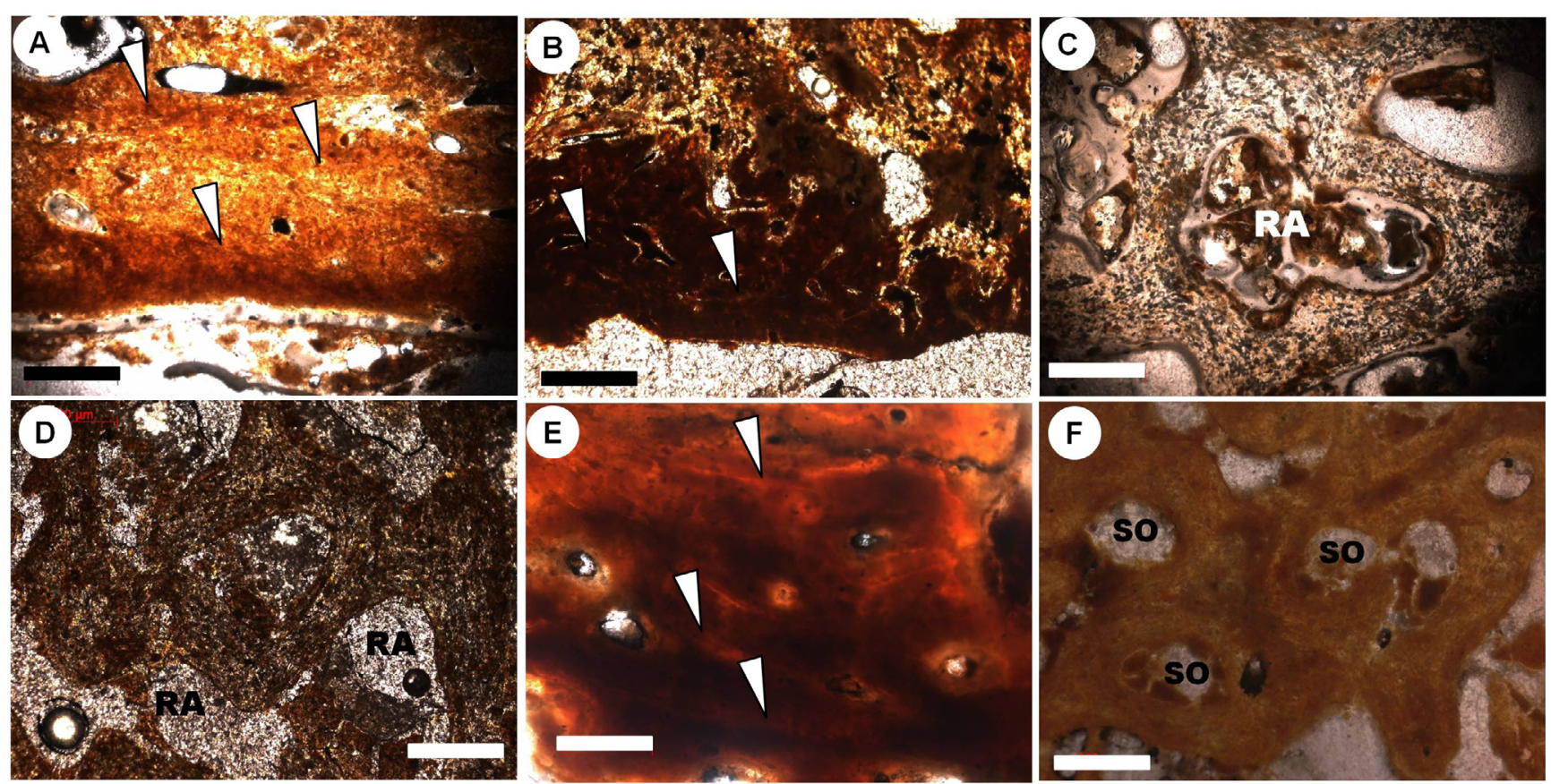

Figure 6. Histological sections of osteoderms from the lateral region of Glyptotherium sp.: A, fibre bundles in the deep layer of compact bone in MCC 2593$\mathrm{V}$ (white arrows); B, fibre bundles with parallel alignment in the compact deep layer of MCC 2096-V (white arrows); C, resorption area in the central region of MCC 2593-V; D, resorption areas in the central region of MCC 2096-V; E, fibre bundles with parallel alignment in the layer of compact surface in MCC 2593-V (white arrows); F, secondary osteons in the compact surface layer of MCC 2096-V. Abbreviations: RA, reabsorption areas; SO, secondary osteons. Scale bars $=200 \mu \mathrm{m}$.
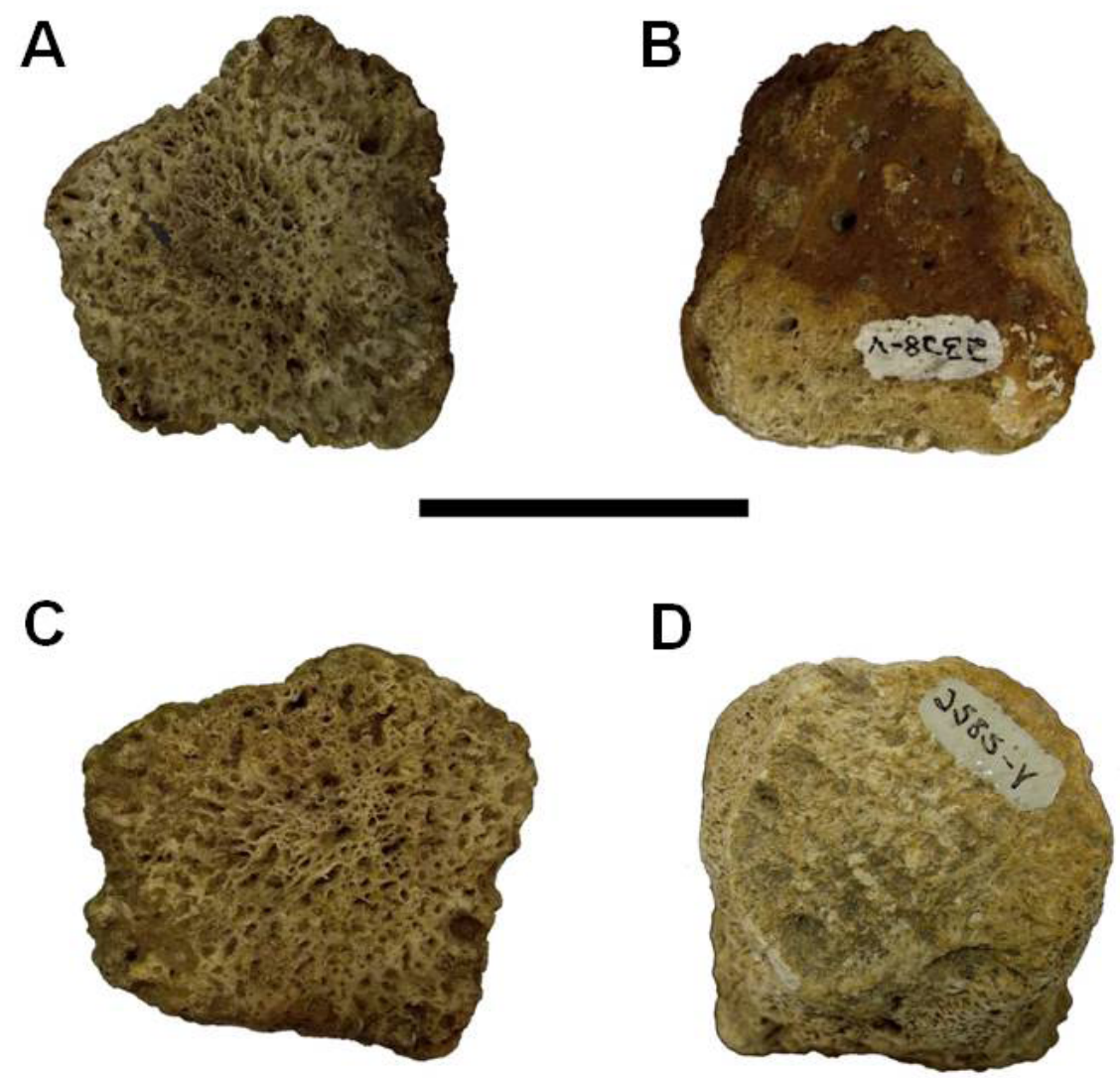

Figure 7. Osteoderms from the region near the posterior border of the Glyptotherium sp. carapace: MCC 2328-V in external (A) and internal (B) views; MCC $2585-\mathrm{V}$ in external $(\mathbf{C})$ and in internal (D) views. Scale bars $=40 \mathrm{~mm}$. 

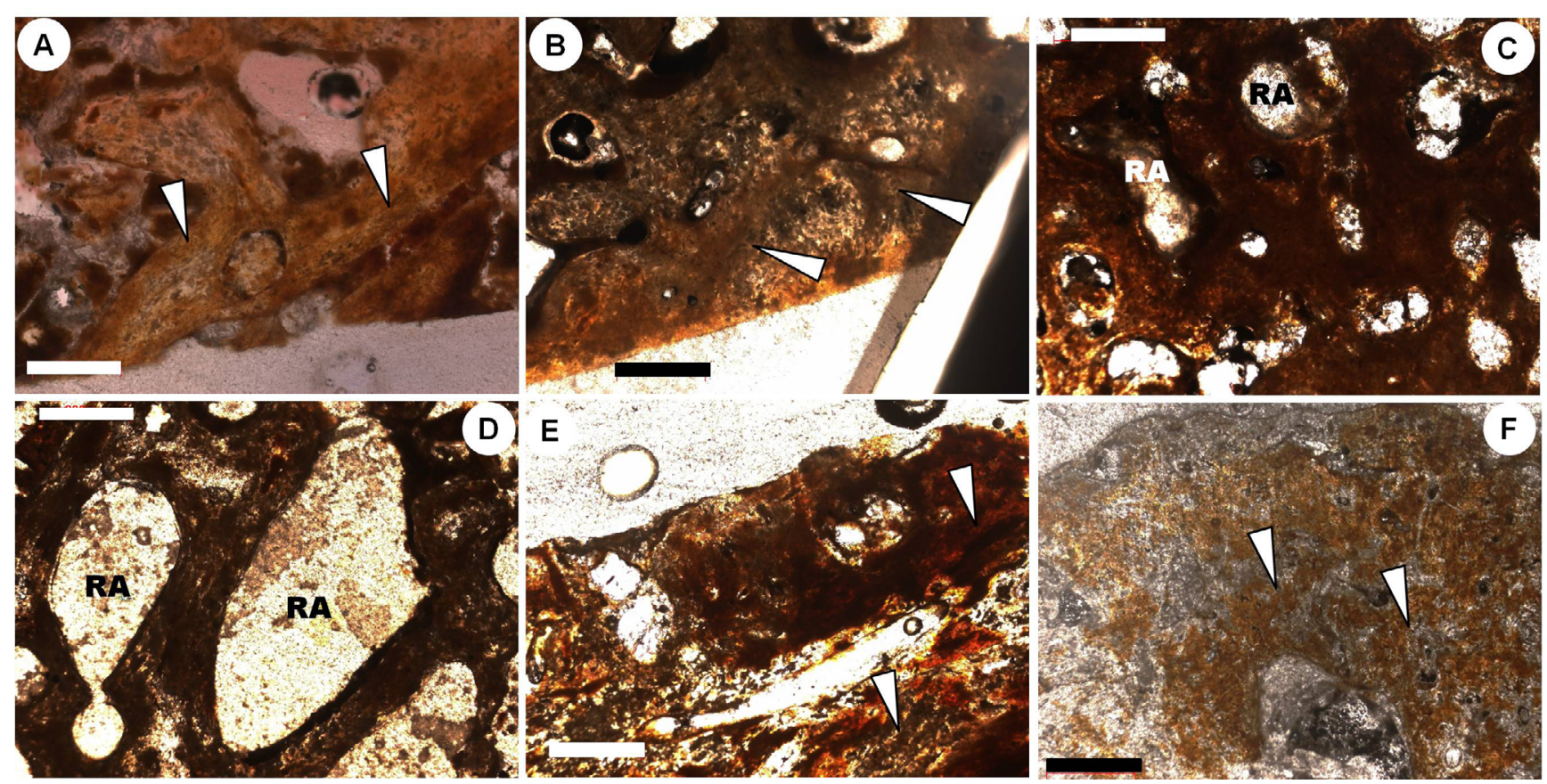

Figure 8. Histological sections of osteoderms located near the posterior border of the Glyptotherium sp. carapace: A, fibre bundles aligned obliquely in the deep compact bone layer of the MCC 2328-V (white arrows); B, fibre bundles aligned obliquely in the compact surface layer of MCC 2585-V (white arrows); C, resorption area in the central region of the MCC 2328-V; D, resorption area in the central region of MCC 2585-V; E, fibre bundles aligned obliquely in MCC 2328-V (white arrows); F, fibre bundles in the MCC 2585-V surface compact layer (white arrows). Abbreviation: RA, resorption areas. Scale bars $=200 \mu \mathrm{m}$.

Family PANOCHTHIDAE Castellanos, 1927

Subfamly PANOCHTHINAE Burmeister, 1866

Panochthus Burmeister, 1866

Panochthus sp.

(Figures 9-14)

Material analysed. Osteoderms: MCC 1616-V, MCC 3254V, MCC 3255-V, MCC 3256-V, MCC 3257-V, MCC 3258-V, MCC 3259-V, MCC 3660-V, MCC 3261-V and MCC 3262-V. Osteoderm from the dorsal region. Referred material: MCC 3259-V (length $=60.84 \mathrm{~mm}$; width $=55.97 \mathrm{~mm}$; thickness $=22.70 \mathrm{~mm}$ ).

Morphological description. The osteoderm of the dorsal region here analysed is nearly hexagonal, with a badly eroded surface, showing signs of abrasion (e.g. rounded edges; Figure 9A). The internal surface shows depressions converging to the centre of the specimen, with 17 neurovascular foramina, most of which are in the centre of this region (Figure 9B).

Histological description. The deep layer of compact bone shows most of the fibre bundles obliquely aligned, and some resorption areas and several osteocytes are also present (Figure 10A). Towards the central region, the amounts of resorption areas - which are vertically elongated - gradually increase. In addition to the reabsorptions areas (Figure 10B), the central region is also characterized by a high number of osteocytes and fibre bundles with varied orientations and some secondary osteons. Towards the superficial layer of compact bone, the number of reabsorption areas diminishes, while osteocytes and primary osteons increase; in this superficial layer, the fibre bundles are obliquely aligned (Figure 10C).

Osteoderms from the lateral region. Referred material: MCC $3258-\mathrm{V}(47.44 \times 35.76 \times 19.80 \mathrm{~mm})$, MCC $3255-\mathrm{V}$ $(36.07 \times 35.48 \times 22.44 \mathrm{~mm})$, MCC $3660-\mathrm{V}(39.05 \times 29.42$ $\times 23.00 \mathrm{~mm})$, MCC $3257-\mathrm{V}(32.93 \times 35.29 \times 23.31 \mathrm{~mm})$.

Morphological description. The osteoderms vary from roughly hexagonal to rectangular. Their external surface is rough, with small polygonal figures (Figures 11A and E) or with a circular main figure surrounded by seven to eight small figures (peripheral figures; Figures $11 \mathrm{C}$ and $\mathrm{G}$ ); the latter are osteoderms close to the lateral border. The internal surface of all of the osteoderms are smooth to gently convex (not discernible in MCC $3255-\mathrm{V}$ due to extensive erosion) and, when present, the neurovascular foramina are few (one to two) (Figures 11B, D, F and H).

Histological description. In the deep layer of compact bone, most fibre bundles are parallel in alignment (Figure $12 \mathrm{~A}$ ); in this layer, there are several osteocytes and primary and secondary osteons (Figure 12B). Towards the central region, the fibre bundles have varied orientations, and small resorptions areas become common. In the central region, these reabsorptions areas are abundant (Figure 12C), larger and horizontally elongated; some osteocytes and primary and secondary osteons are also observed (Figure 12D). Towards the superficial layer of compact bone, parallel fibre bundles appear (Figure 12E), although in some portions they are more obliquely oriented; this region also presents 


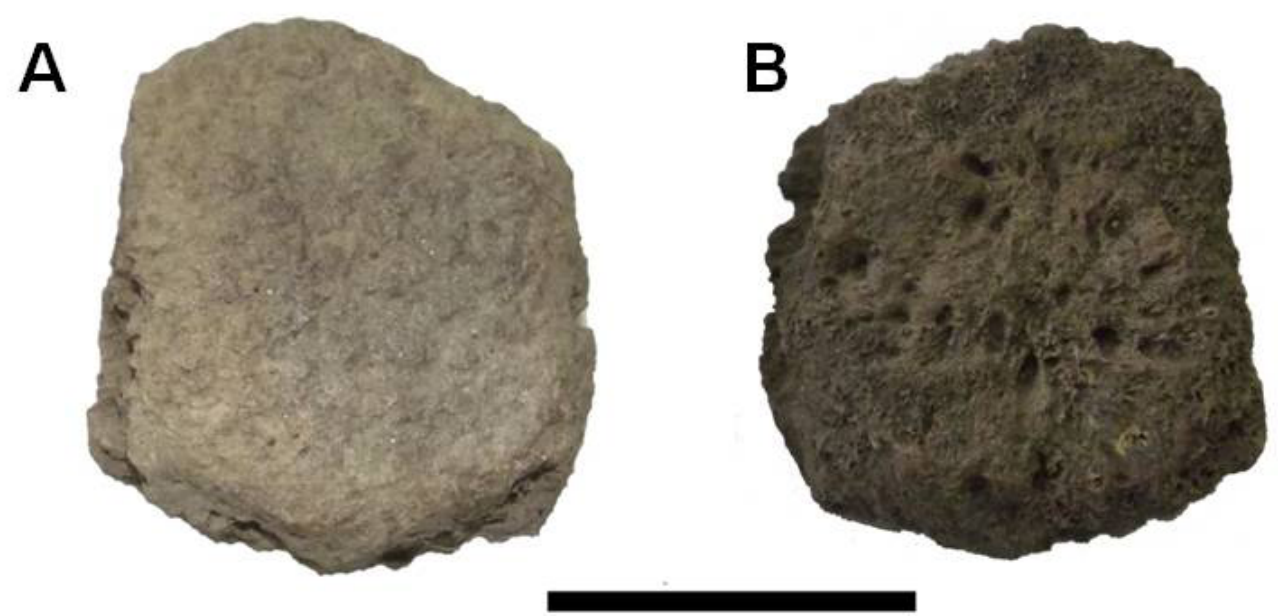

Figure 9. Osteoderms from the dorsal region of the Panochthus sp. carapace. MCC 3259-V in external (A) and internal (B) views. Scale bar $=40 \mathrm{~mm}$.
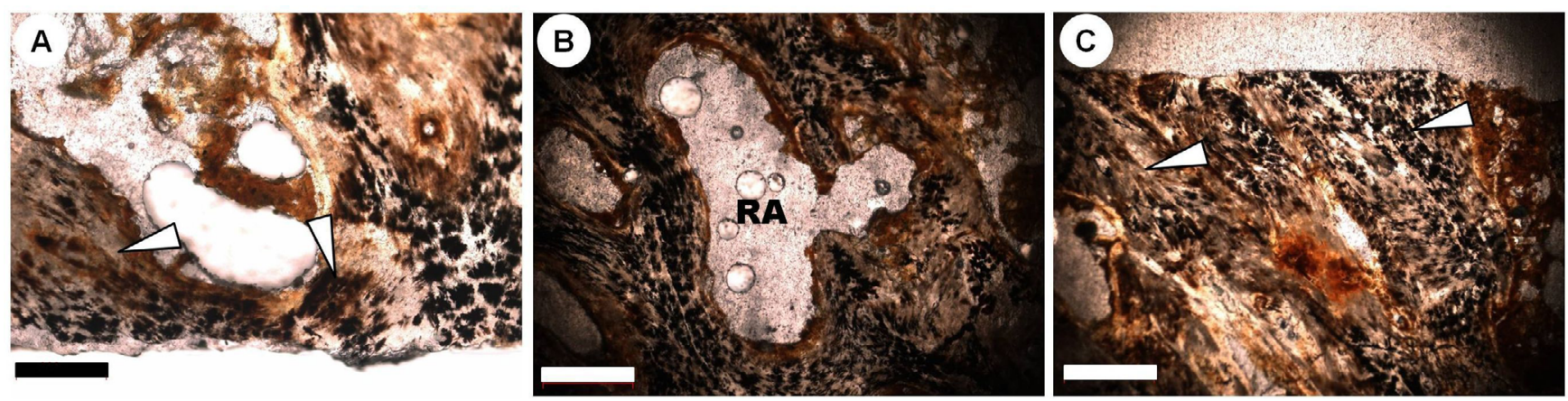

Figure 10. Histological sections of the osteoderms from the dorsal region of the Panochthus sp. carapace: A, fibre bundles with oblique alignment in the deep compact bone layer of MCC 3259-V (white arrows); B, resorption areas of in the central region of MCC 3259-V (white arrows); $\mathbf{C}$, fibre bundles with oblique alignment in the compact surface layer of MCC 3259-V (white arrows). Abbreviations: RA, resorption areas. Scale bars $=200 \mu \mathrm{m}$.

several osteocytes and some primary and secondary osteons (Figure 12F).

Osteoderms with ante mortem alterations. Referred material: MCC $3262-\mathrm{V}(43.98 \times 36.69 \times 21.18 \mathrm{~mm})$, MCC $3254-\mathrm{V}(38.64 \times 32.33 \times 21.40 \mathrm{~mm}), \mathrm{MCC} 3261-\mathrm{V}(40.61$ $\times 31.97 \times 17.27 \mathrm{~mm})$, MCC $3256-\mathrm{V}(38.00 \times 26.20 \times 18.11$ $\mathrm{mm})$ and MCC $1616-\mathrm{V}(42.27 \times 35.77 \times 21.19 \mathrm{~mm})$.

Morphological description. The osteoderms 3262-V (Figures $13 \mathrm{~A}$ and B), 3254-V (Figures 13C and D), MCC 3261-V (Figures 13E and F) and MCC 3256-V (Figures 13G and H) are rectangular and likely belong to the lateral region of the carapace; their external surfaces are eroded, with a very porous aspect due to the exposition of trabecular bone. In lateral view, these osteoderms preserve their original serrated morphology. Their internal surfaces are smooth to slightly convex, with several neurovascular foramina, among which one to five foramina are larger. The osteoderm MCC 1616-V (Figures 13I and J) clearly belongs to the posterior border of the carapace, likely from its more lateral sections. It is more quadrangular, with a posteriorly displaced main figure with a rounded outlined along its posterior edge. For the remaining altered osteoderms, their external surfaces are very porous, with an eroded aspect; at the centre of the main figure, there is a very rough depression (Figure 13I). Its internal surface, in turn, is smooth with around ten neurovascular foramina of different sizes (Figure 13J).

Histological description. Overall, the histology of the altered osteoderms is characterized by a deep layer containing fibre bundles with no discernible preferential direction (Figure $14 \mathrm{~A})$, several osteocytes, some primary and secondary osteons (Figure 14B), and some small resorption areas. Towards the central region, there are large resorption areas (Figure 14C), which possess the typical trabecular aspect of this region. In addition, there are some osteocytes, primary and secondary osteons (Figure 14D). Towards the superficial layer of compact bone, the resorption areas diminish in both size and quantity. In the superficial layer, there are several osteocytes, some osteons and resorption areas (Figure 14E) and fibre bundles with no preferential alignment (Figure 14F).

\section{DISCUSSION}

All osteoderms evaluated in this paper present a "diplöelike" structure, which consists of a central region of trabecular bone sandwiched between superficial and deep layers of compact bone, as in other previously described osteoderms of cingulates (e.g. Hill, 2006; Wolf, 2007; Wolf et al., 2012; Pereira et al., 2014; Asakura et al., 2017). In addition, we noted that the specimens studied present extensive bone remodelling, 
A

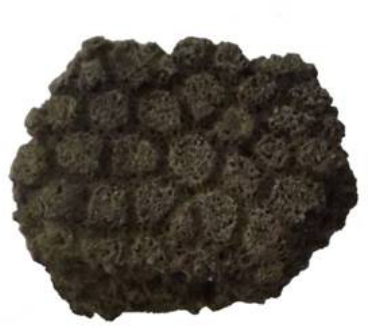

B

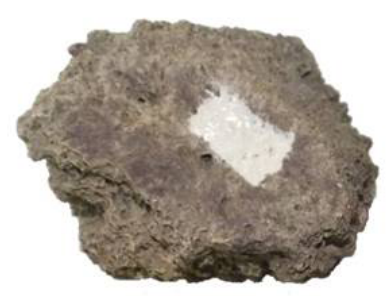

(2)

$E$

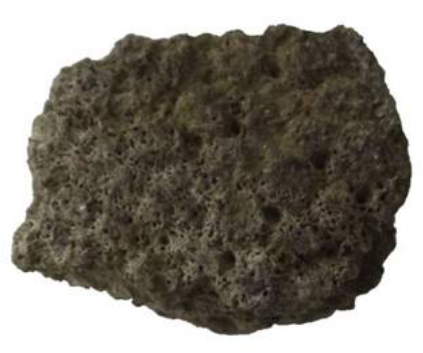

$\mathbf{F}$

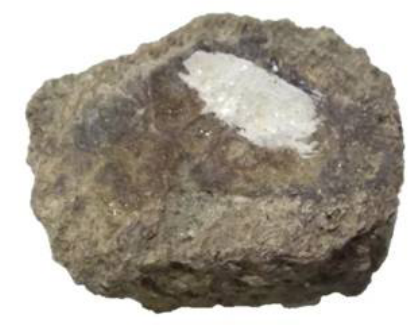

C

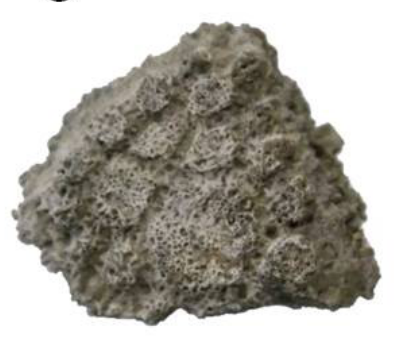

D

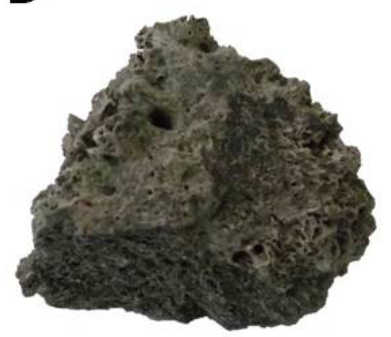

G

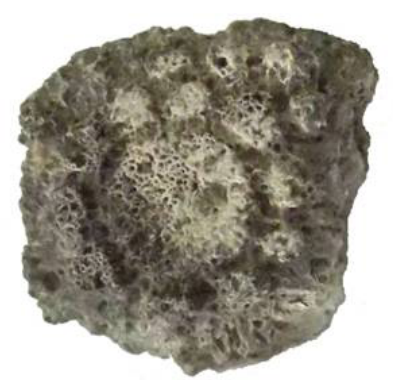

H

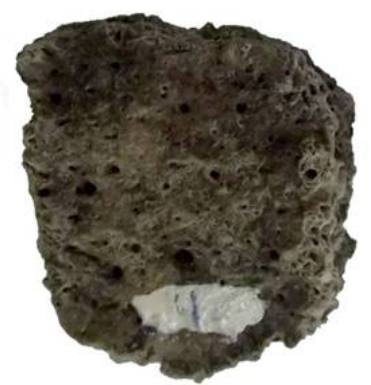

Figure 11. Osteoderms from the lateral region of the Panochthus sp. carapace. MCC 3258-V in external (A) and internal (B) views; MCC 3255-V in external (C) and internal (D) views; 3660-V in external (E) and internal (F) views; MCC 3257-V in external (G) and internal (H) views. Scale bars $=30 \mathrm{~mm}$.

which seems a remarkable characteristic of glyptodont osteoderms (Wolf, 2007). Comparing the osteoderms of the genera here analysed, we observe that those of Glyptotherium show layers of thicker compact bone than in Panochthus, while those of the latter have a more porous aspect.

The osteoderms of Glyptotherium sp. here analysed share a central region dominated by a large resorption area, with few primary and secondary osteons. On the other hand, there are differences between the superficial and deep layers of compact bone among osteoderms from different regions of the carapace. Osteoderms from the mid-dorsal section of the dorsal region exhibit fibre bundles with a parallel alignment in both layers of compact bone, while the osteoderms from the lateral region have both parallel and obliquely aligned fibre bundles in the deep and superficial layers, respectively. The osteoderms from the posterodorsal section near the posterior border, in turn, have obliquely aligned fibre bundles in both layers of compact bone.

The specimens from the dorsal region of the Glyptotherium sp. studied here (MCC 1234-V, MCC 2601-V, MCC 2579-V, MCC 2092-V) are similar to those analysed by Pereira et al. (2014), which are also from the same region of the carapace and study location (Lajedo da Escada). The specimens evaluated here show, in their deep layer of compact bone, fibre bundles with dominantly parallel alignment, some primary and secondary osteons, a central region with several resorption areas and several osteocytes and secondary osteons; in addition, their superficial layer of compact bone shows fibre bundles with parallel alignment and some osteocytes and osteons. These histological patterns concur with those described by Pereira et al. (2014), except for the deep layer of compact bone for which there is no available information regarding the orientation of the fibre bundles in the mentioned paper, precluding a more complete comparison.

The osteoderms from the lateral region and those closer to the posterior border of the carapace show some differences when compared with osteoderms from the dorsal region, as described by Pereira et al. (2014). The osteoderms from the lateral region have fibre bundles with parallel and oblique alignment in the deep and superficial layers of compact bone, respectively. The osteoderms from the posterodorsal section near the posterior border of the carapace bear obliquely oriented fibre bundles in both layers. This pattern is different from the osteoderms of the dorsal region (including the one described by Oliveira et al., 2014), which present fibre bundles with parallel alignment in both layers.

Curiously, the osteoderms from the posterodorsal section near the posterior border described here are histologically similar to the Glyptotherium floridanum exemplar described by Hill (2006), although they differ from the latter in external morphology because they are not from comparable regions. They share obliquely aligned fibre bundles in the 

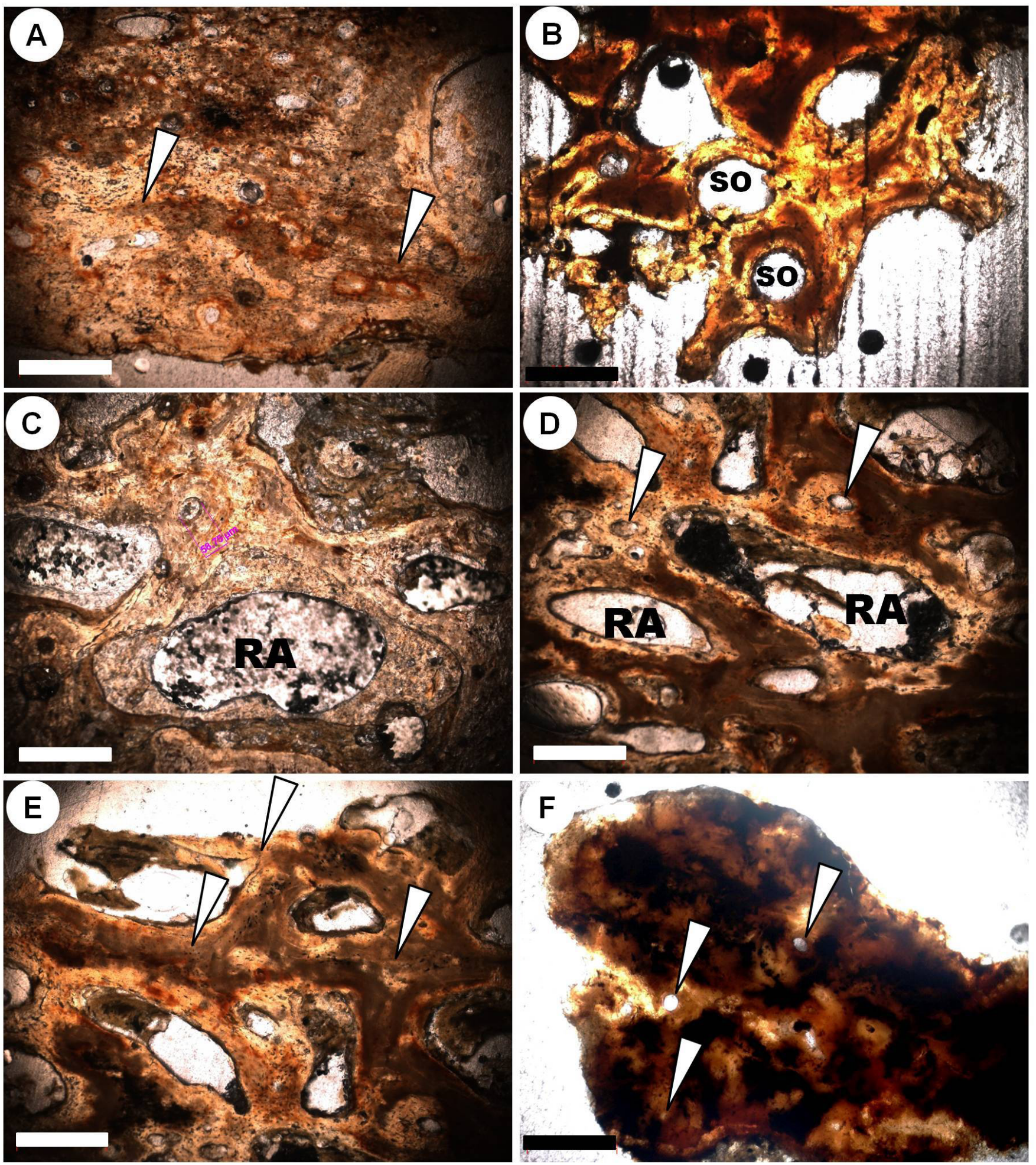

Figure 12. Histological sections of osteoderms from the lateral region of the Panochthus sp. carapace. A, fibre bundles aligned parallel to the deep compact layer of MCC 3660-V (white arrows); B, secondary osteons in the deep compact layer of MCC 3258-V; C, resorption areas in the central region of MCC 3255 $\mathrm{V}$ (white arrows); D, primary osteons in the central region of MCC 3660-V (white arrows); E, fibre bundles with parallel alignment in the compact surface layer of MCC 3660-V (white arrows); F, primary osteons in the compact surface layer of MCC 3257-V (white arrows). Abbreviations: RA, reabsorption areas; SO, secondary osteon. Scale bars $=200 \mu \mathrm{m}$.

superficial and deep layers of compact bone, differing only in the number of primary osteons, which are few in the specimens here analysed but copious in the specimens described by Hill (2006). These results suggest caution when searching for histological characters useful for taxonomic decisions and phylogenetic inference based on isolated osteoderms, especially when no carapace positional information is available. 
A
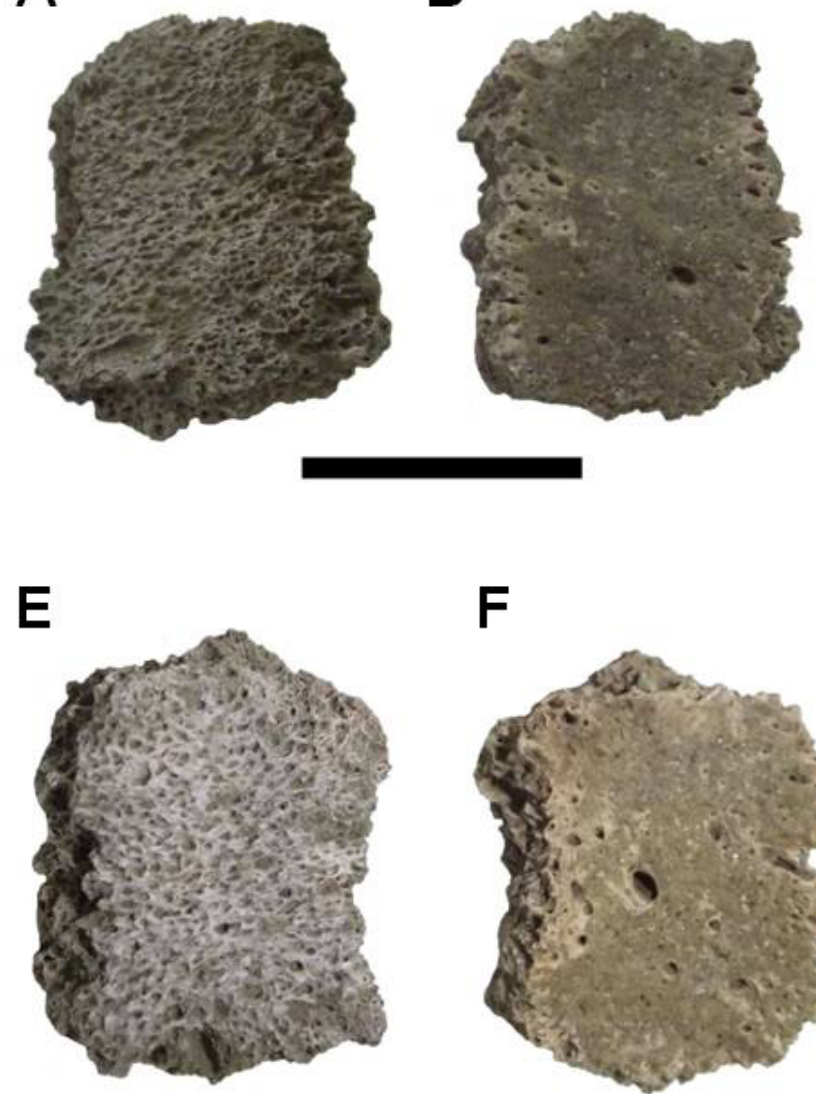

B

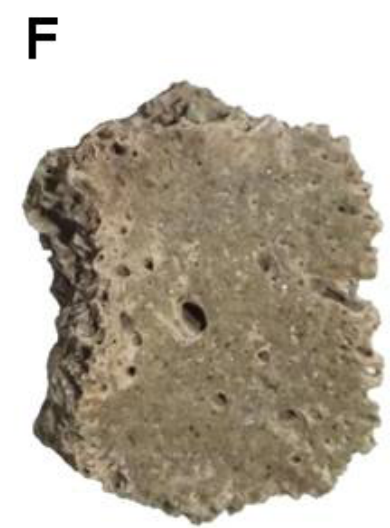

C

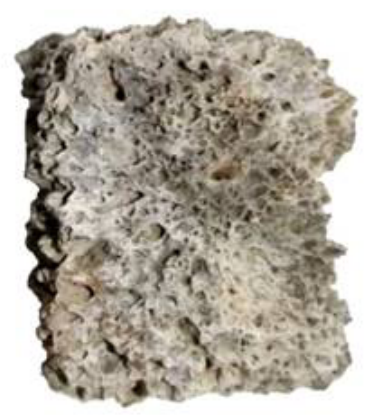

D

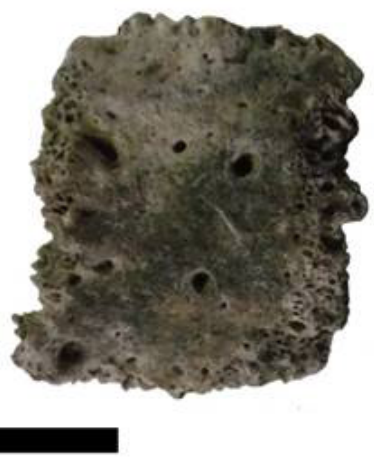

G

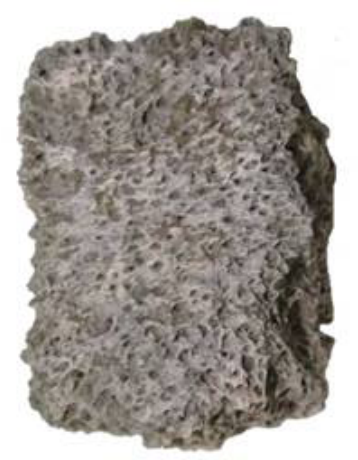

$\mathrm{H}$

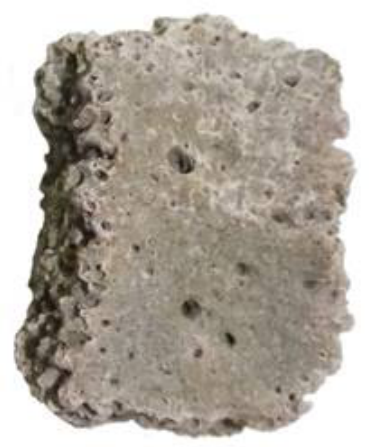

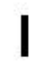

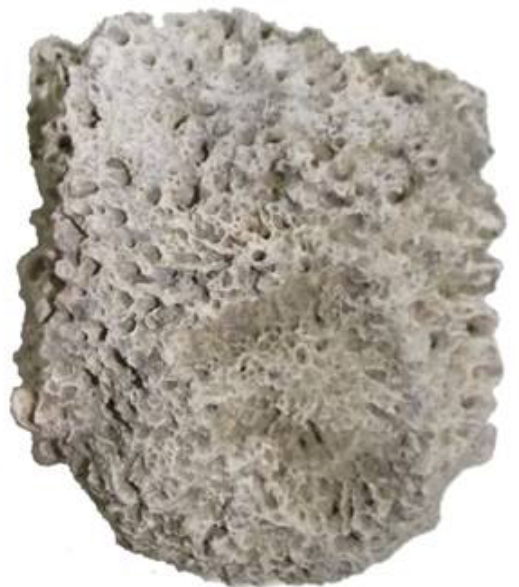

J

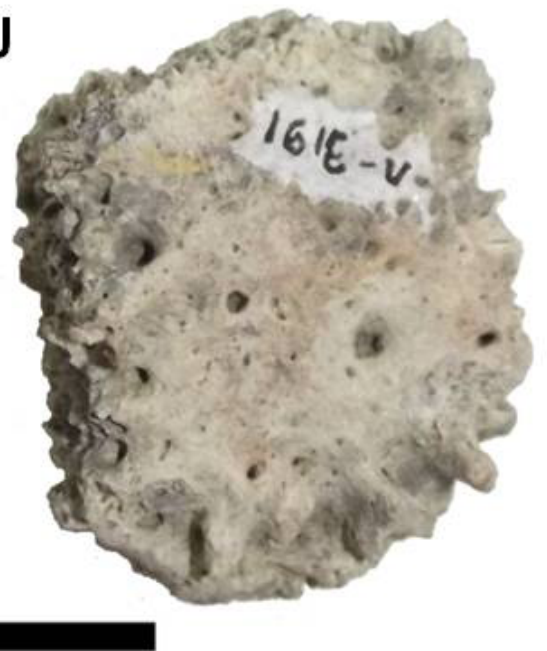

Figure 13. Altered osteoderms of Panochthus sp. MCC 3262-V in external (A) and internal view (B); MCC 3254-V in external (C) and internal (D) views; MCC 3261-V in external (E) and internal (F) views; MCC 3256-V in external (G) and internal (H) views; MCC 1616-V from the posterior border in external (I) and in internal (J) views. Scale bars $=30 \mathrm{~mm}$.

A comparison between the osteoderms of Glyptotherium described here and the osteoderm of Glyptodon reticulatus studied by Hill (2006) shows that the exemplars of the former taxon do not exhibit the coexistence of fibre bundles without discernible or perpendicular alignment in the deep and superficial layers, respectively, in contrast to G. reticulatus. This difference offers additional potential evidence to differentiate Glyptotherium and Glyptodon in addition to the macroscopic distinctive characters (see, for example, Oliveira et al., 2010) and concurs with Oliveira et al. (2010) and Pereira et al. (2014) in assigning the Glyptodontinae specimens of the Lajedo da Escada Site to Glyptotherium rather than Glyptodon. 

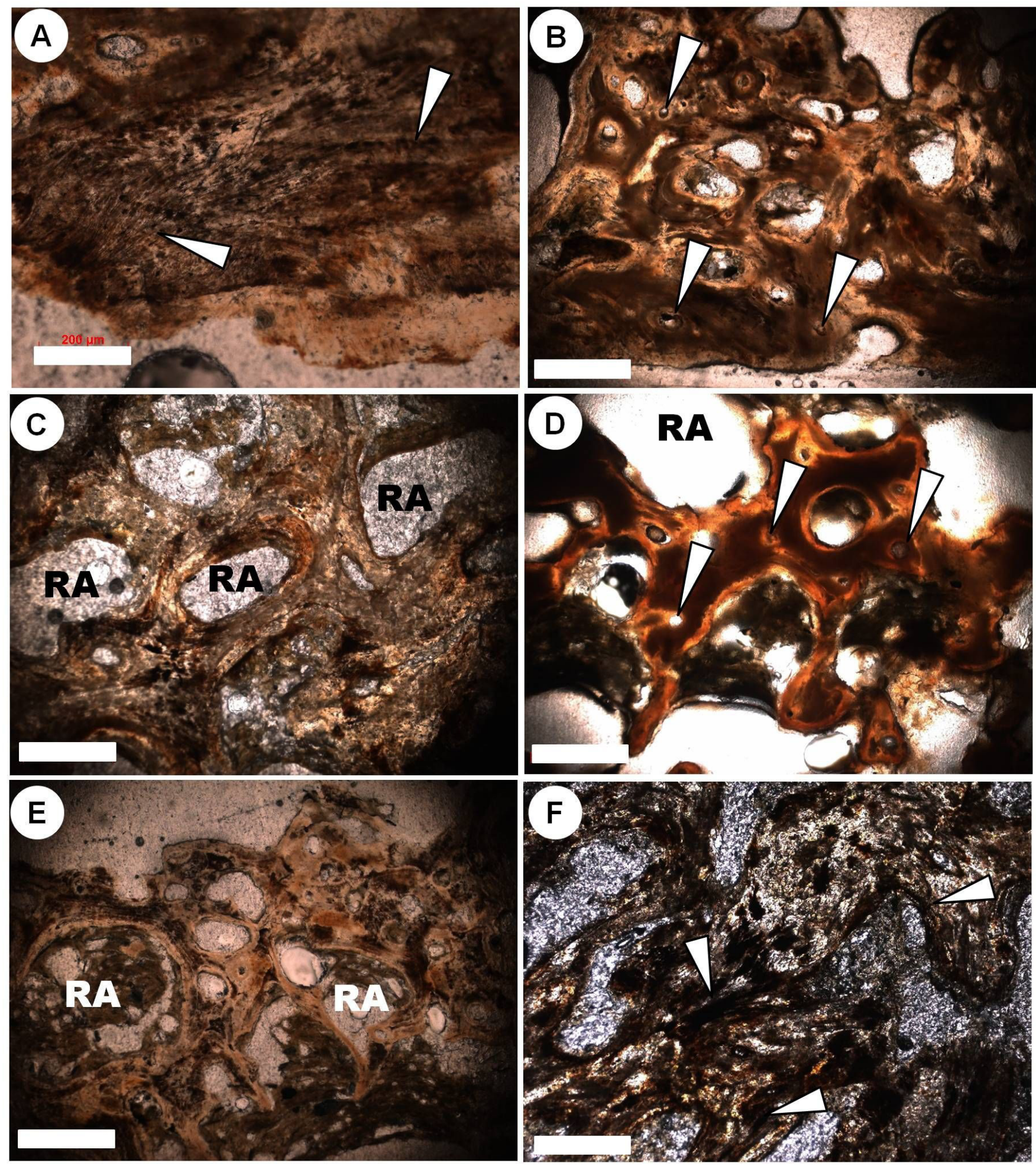

Figure 14. Histological sections of the altered osteoderms of Panochthus sp. A, Fibre bundles with no preferential alignment in the deep compact layer of MCC 3262-V (white arrows); B, primary osteons in the deep compact layer of MCC 3261-V (white arrows); C, resorption areas in the central region of osteoderm MCC 3254-V; D, primary ossicles in the central region of MCC 3256-V (white arrows); E, resorption areas in the superficial compact bone layer; F, fibre bundles without preferential alignment in the compact surface layer of MCC 3256-V. Abbreviations: RA, reabsorption areas; SO, secondary osteon. Scale bars $=200 \mu \mathrm{m}$.

With regard to the inferred closer affinity among Glyptotherium, Doedicurus and Glyptodon, which form the Glyptodontinae clade (sensu Fernicola, 2008; see also Fernicola \& Porpino, 2012), we observed that the Glyptotherium osteoderms described here and the Doedicurus and Glyptodon osteoderms previously described (e.g. Hill, 2006) share a markedly remodeled central region with several large resorption areas, in contrast to Panochthus (Hill, 2006; Pereira et al., 2014; this work). This observation provides potential new evidence supporting this clade. 
All osteoderms for Panochthus described here share a central region with several horizontally elongated resorption areas, bearing some osteocytes and primary and secondary osteons. The altered osteoderms (including the one from the posterior border) are histologically very similar in that they have superficial and deep compact bone layers with fibre bundles without preferential orientation. However, the osteoderms from the dorsal and lateral regions show differences when their compact bone layers (superficial and deep) are compared. Most of the fibre bundles of specimen MCC 3259-V (dorsal region) are obliquely oriented, while the osteoderms of the lateral region have fibre bundles aligned parallel to the external surface.

The osteoderm from dorsal region $3259-\mathrm{V}$ shares some characters with the Panochthus frenzelianus exemplar described by Hill (2006), which is also likely from the same region of the carapace, including fibre bundles in the deep layer of compact bone that are mostly obliquely oriented and a central region with a great amount of resorption areas. Conversely, the superficial compact bone layer in MCC 3259$\mathrm{V}$ shows fibre bundles with oblique alignment rather than parallel, as in P. frenzelianus (Hill 2006). This difference may indicate a possible interspecific variation that could be useful in distinguishing these species, considering that the coexistence of parallel and obliquely aligned fibre bundles in the superficial and deep layers of compact bone as described for the specimens of $P$. frenzelianus in Hill (2006) was not observed in any of the Panochthus sp. osteoderms described here.

Curiously, MCC 3259-V shows differences with respect to the osteoderm from the dorsal region described by Pereira et al. (2014), which is from the same deposit. The exemplar described by Pereira et al. (2014) has parallel fibre bundles in both the superficial and deep layers of compact bone, in contrast to the pattern observed in MCC 3259-V, in which the fibre bundles are obliquely aligned in both layers. Surprisingly, the histological pattern of MCC $3259-\mathrm{V}$ is very similar to that of specimen MCC $1089-\mathrm{V}$ described by Pereira et al. (2014), which is likely a fragment of the cephalic shield found in the same deposit (see Porpino et al., 2014). Both show obliquely aligned fibre bundles in the superficial and deep layers of compact bone and a central region with a less porous aspect and smaller resorption areas, compared to other osteoderms of Panochthus sp. described here and in Pereira et al. (2014). This observation implies that the histological pattern for distinct parts of the exoskeleton (i.e. a carapace and cephalic shield), at least in this genus, may coincide in some instances, even if their external morphology is strikingly different.

In regard to the histological pattern of the osteoderms with ante mortem alterations, we noted that they share several features such as fibre bundles without preferential alignment, few osteocytes and osteons in the deep and superficial layers of compact bone, and a highly porous central region with great resorption areas. It is possible that the fibre bundles lack a discernible orientation in the more superficial parts of these specimens due to the erosive process that eroded their surfaces, creating a more rough and porous aspect (Barbosa \&
Luna, 2014). In fact, these erosive processes may have eroded most of the superficial layer of compact bone, exposing, in the most superficial areas of the osteoderms, the intermediate zone (observed in the remaining osteoderms of Panochthus described here) just below the superficial compact layer, which is characterized by fibre bundles with no preferred alignment (Pereira et al., 2014).

The osteoderms of Panochthus sp. recently described by Asakura et al. (2017) are histologically similar to the osteoderms of the lateral region of this genus described here, in that they have superficial and deep layers of compact bone with fibre bundles that have a parallel orientation and few osteons. In addition, they also share a porous central region, with great resorption areas. In comparison to the osteoderms described here from the dorsal region and the altered ones, the osteoderms described by Asakura et al. (2017) show some differences, part of which may be due to alteration (in the case of the altered ones). However, the differences observed with regard to the non-altered osteoderms described here is difficult to ascertain because a) Asakura et al. (2017) did not specify the region of the carapace from which the osteoderms they study come from; and b) there is currently no sound basis in assigning isolated osteoderms to the species of Panochthus occurring in the Brazilian Intertropical Region (i.e. P. greslebini and P. jaguaribensis) unless, as stated earlier, a clear association between isolated specimens with caudal tubes (or parts of the caudal tube preserving the diagnostic characters) is clearly established (see Porpino et al., 2014).

Curiously, the histological organization described by Asakura et al. (2017) for specimens of Neuryurus sp., including fibre bundles with no preferred orientation in the superficial and deep layers of compact bone and a central region with elongated resorption areas, is similar to that of specimens bearing ante mortem alterations described here, although the description offered by those authors is not equally detailed for all specimens they studied. The altered specimens of Panochthus sp. described here do not show the typical external ornamentation pattern of the genus due to an extensive erosive process that gave their external surfaces a very rough aspect, and several foramina (likely representing the trabecular tissue exposure). At first glance, this rough and porous aspect bears a resemblance to the external surface of Neuryurus osteoderms, which are characterized by the absence of polygonal figures and by the presence of several foramina (Ameghino, 1889; Zurita et al., 2006; Zurita \& Ferrero, 2009). It is worth noting, however, that the altered osteoderms of Panochthus studied here were found in association with the partial carapace MCC $1603 \mathrm{~V}$, as stated above (see Oliveira et al., 1984; Porpino et al., 2014, fig. 5G). The specimen MCC 1603 bears osteoderms with the diagnostic external ornamentation pattern of the genus, but show, in some parts, osteoderms with eroded ornamentation alongside osteoderms with intact ornamentation (like in the carapace described by Barbosa \& Luna, 2014). Therefore, it is more parsimonious to infer that the altered osteoderms described here belong to Panochthus and are likely part of this mentioned carapace rather than to Neuryurus. This conclusion 
is reinforced by the fact that there is no additional evidence of the latter genus in the deposit from which the material was collected (e.g. osteoderms of the caudal armor, which are clearly distinct from the homologous elements of Panochthus; see, for instance, Ameghino, 1889, pl. LXI).

In addition, when we compared the ornamentation pattern of the Neuryurus rudis (the type-species of Neuryurus) osteoderms figured by Ameghino (1889), those of a partial carapace of Neuryurus sp. described by Zurita et al. (2006) and the one figured by Asakura et al. (2017) with the altered osteoderms described here, we noted that, despite some similarities, the latter presents a much rougher external aspect with larger foramina that resemble the trabecular tissue. In contrast, the osteoderms described by Zurita et al. (2006) and Asakura et al. (2017) show some tubercles in the external surface not observed in the altered specimens examined here. In the face of these macroscopic differences, one reasonable explanation is that a likely pathological process eroded most of the superficial layer of compact bone in the altered osteoderm of Panochthus. This erosion exposed the intermediate zone between the superficial layer of compact bone and the central region of trabecular bone (see above), which have fibre bundles without a preferred alignment, as in the superficial layer of compact bone in the Neuryurus osteoderms described by Asakura et al. (2017).

Conversely, there is an intriguing similarity between the altered osteoderms described here and those of Neuryurus trabeculatus (Zurita \& Ferrero, 2009) in terms of the external surface, which is also very similar to trabecular tissue and differs from the specimens of Neuryurus previously described, such as those in Ameghino (1889), Zurita et al. (2006) and Asakura et al. (2017). This peculiar external morphology of the altered osteoderms described here and those of $N$. trabeculatus is remarkably similar to that of some pathologically affected Panochthus osteoderms described and figured by Barbosa \& Luna (2014). At first glance, this similarity suggests the possibility that $N$. trabeculatus is a pathologically affected individual of Panochthus, like the altered osteoderms described here. However, there are some differences, such as the presence of large foramina along the internal surface of the osteoderms assigned to $N$. trabeculatus, which are not observed in both the altered and non-altered Panochthus osteoderms described here. Therefore, while it is reasonable to infer that the osteoderms MCC 3262-V, MCC 3254-V, MCC 3261-V, MCC 3256-V and MCC 1616-V are pathologically altered specimens of Panochthus, detailed comparisons, including histological information not yet available to $N$. trabeculatus, are necessary in order to figure out the implication for these similarities in our understanding of the latter species.

\section{CONCLUSIONS}

Our analysis shows that there are histological variations among osteoderms from different regions of the carapace in Glyptotherium and Panochthus. The osteoderms from the lateral and dorsal regions of Glyptotherium sp. show histological differences relative to the osteoderms of $G$. floridanum previously described. Conversely, the ostederms closer to the posterior border are similar in Glyptotherium sp. and G. floridanum. This evidence suggests that specific differentiation based on histological patterns should be proposed with caution. Our analysis also shows histological characters shared by Glyptotherium sp., Glyptodon and Doedicurus, which reinforces the phylogenetic affinities among these taxa, as suggested in some current phylogenetic analyses. In addition, we found histological differences in the osteoderms of Glyptotherium and Glyptodon reticulatus that show the potential of these sorts of features in order to distinguish Glyptotherium from Glyptodon, considering that most macroscopic differences in osteoderms are subtle.

With regard to the osteoderms of Panochthus sp., we observed that they bear a central region with common characters regardless of the position they occupy in the carapace. The altered osteoderms of this genus studied here share very similar compact layers, especially in having fibre bundles with no preferred alignment, in contrast to osteoderms from the dorsal region, which show obliquely aligned fibre bundles in the compact layers of bone. These altered osteoderms also differ from the non-altered osteoderms of the lateral region, which possess fibre bundles with parallel alignment in the mentioned layers. Intriguingly, the histological pattern of these altered osteoderms is similar to the one observed in osteoderms of Neuryurus recently described, though macroscopic differences exist. The likely explanation for this similarity is that some pathological processes may have eroded the superficial layers of compact bone in these altered osteoderms, exposing the fibre bundles without preferred alignment, which are characteristic of the intermediate layer between the superficial layer of compact bone and the central region.

\section{ACKNOWLEDGEMENTS}

The authors would like to thank M.F.C.F. Santos (MCC) for the donation of the osteoderms described here; H.I. Araújo-Júnior, A.B.L Fragoso e D. Peretti for their thoughtful comments on an early version of this manuscript; N.M. Silva e L. Melo (Universidade Estadual do Rio de Janeiro) for their help in the preparation of the thin sections; G.P.O. Martins for the photo in Figure 2C; L.P. Bergqvist and an anonymous reviewer for their valuable comments and suggestions; and Coordenação de Aperfeiçoamento de Pessoal de Nível Superior (CAPES) and Conselho Nacional de Desenvolvimento Científico e Tecnológico - CNPq (grant $308013 / 2015$, KOP) for the financial support.

\section{REFERENCES}

Ameghino, F. 1889. Contribución al conocimiento de los mamíferos fósiles de la Republica Argentina. Actas de la Academia Nacional de Ciencias de Cordoba, 6:1-1027.

Araújo-Júnior, H.I.; Porpino, K.O.; Ximenes, C.L. \& Bergqvist, L.P. 2011. Análise multivariada como ferramenta tafonômica no estudo das associações quaternárias de mamíferos do 
Nordeste do Brasil. Gaea - Journal of Geoscience, 7:104-111. doi:10.4013/gaea.2011.72.03

Araújo-Júnior, H.I.; Porpino, K.O.; Ximenes, C.L. \& Bergqvist, L.P. 2013. Unveiling the taphonomy of elusive natural tank deposits: a study case in the Pleistocene of northeastern Brazil. Palaeogeography, Palaeoclimatology, Palaeoecology, 378:5274. doi:10.1016/j.palaeo.2013.04.001

Asakura, Y.; Da Costa, P.V.L.G.; Oliveira, E.V. \& Da Silva, J.L.L. 2017. Comparative paleohistology in osteoderms of Pleistocene Panochthus sp. Burmeister, 1886 and Neuryurus sp. Ameghino, 1889 (Xenarthra, Glyptodontidae). Comptes Rendus Palevol, 16:795-803. doi: doi.org/10.1016/j.crpv.2017.05.006

Barbosa, F.H.S. \& Luna, C.A. 2014. Lesiones en la coraza y endoesqueleto de un ejemplar de Panochthus Burmeister, 1866 (Mammalia, Glyptodontia) de la provincia de Córdoba, Argentina. Revista del Museo Provincial de Ciencias Naturales "Dr. Arturo Umberto Illia”, 1:9-26.

Barbosa, F.H.S.; Porpino, K.O.; Fragoso, A.B. \& Oliveira, E.V. 2014. Arthritis in a glyptodont (Mammalia, Xenarthra, Cingulata). PLoS ONE, 9:e88646. doi:10.1371/journal.pone.0088646

Carvalho, J.N.C. et al. 1966. Informação sobre a jazida fossilifera pleistocênica do Lajedo da Escada, município de Mossoró, Rio Grande do Norte. Natal, Arquivos do Instituto de Antropologia, UFRN, p. 391-404.

Castellanos, A. 1942. A proposito de los géneros Plohophorus, Nopachthus y Panochthus (Tercera parte). Santa Fe, Instituto de Fisiografia y Geologia de la Universidad Nacional del Litoral, p. 417-592 (Publicaciones 11).

Delsuc, F. et al. 2016. The phylogenetic affinities of the extinct glyptodonts. Current Biology, 26:R155-R156. doi:10.1016/j. cub.2016.01.039

Fariña, R.A.; Vizcaíno, S.F. \& De Iuliis, G. 2013. Megafauna: giant beasts of Pleistocene South America. $1^{\text {st }}$ ed. Bloomington, Indiana University Press, 448 p.

Fernicola, J.C. 2008. Nuevos aportes para la sistemática de los Glyptodontia Ameghino 1889 (Mammalia, Xenarthra, Cingulata). Ameghiniana, 45:553-574.

Fernicola, J.C. \& Porpino, K.O. 2012. Exoskeleton and systematics: a historical problem in the classification of glyptodonts. Journal of Mammalian Evolution, 19:171-183. doi:10.1007/s10914012-9186-1

França, L.; Dantas, M.A.T.; Bocchiglieri, A.; Cherckinsky, A.; Ribeiro, A.S. \& Bocherens, H. 2014. Chronology and ancient feeding ecology of two upper Pleistocene megamammals from the Brazilian Intertropical Region. Quaternary Science Reviews, 99:78-83. doi:10.1016/j.quascirev.2014.04.028

Gillette, D.D.; Carranza-Castañeda, Ó.; White Jr., R.S.; Morgan, G.S.; Thrasher, L.C.; McCord, R. \& McCullough, G. 2016. Ontogeny and sexual dimorphism of Glyptotherium texanum (Xenarthra, Cingulata) from the Pliocene and Pleistocene (Blancan and Irvingtonian NALMA) of Arizona, New Mexico, and Mexico. Journal of Mammalian Evolution, 23:133-154. doi:10.1007/s10914-015-9309-6

Hill, R.V. 2006. Comparative anatomy and histology of xenarthran osteoderms. Journal of Morphology, 267:1441-1460. doi:10.1002/jmor.10490

Moreira, L.E. 1965. Notas prévias sobre nova espécie de mamífero fóssil do Estado do Ceará. Hy Hy Te (Revista da Faculdade de Filosofia do Crato), 2:41-49.
Moreira, L.E. 1971. Os gliptodontes do nordeste do Brasil. Anais da Academia Brasileira de Ciências, 43:529-552.

Oliveira, É.V.; Porpino, K.O. \& Barreto, A.F. 2010. On the presence of Glyptotherium in the Late Pleistocene of Northeastern Brazil, and the status of "Glyptodon" and "Chlamydotherium". Paleobiogeographic implications. Neues Jahrbuch für Geologie und Paläontologie-Abhandlungen, 258:353-363. doi:10.1127/0077-7749/2010/0116

Oliveira, L.D.D.; Santos, C.L.A. \& Santos, M.F.C.F. 1984. Nova ocorrência de Panochthus greslebini Castellanos, 1941, no Estado do Rio Grande do Norte. Recife, Núcleo Nordeste da Sociedade Brasileira de Geologia, p. 346-351 (Boletim 9).

Paula-Couto, C. 1979. Tratado de Paleomastozoologia. Rio de Janeiro, Academia Brasileira de Ciências, 590 p.

Pereira, P.V.L.G.C.; Victer, G.D.; Porpino, K.O. \& Bergqvist, L.P. 2014. Osteoderm histology of Late Pleistocene cingulates from the intertropical region of Brazil. Acta Palaeontologica Polonica, 59:543-552. doi:10.4202/app.2011.0117

Porpino, K.O. \& Bergqvist, L.P. 2002. Novos achados de Panochthus (Mammalia, Cingulata, Glyptodontoidea) no Nordeste do Brasil. Revista Brasileira de Paleontologia, 4:51-62.

Porpino, K.O.; Fernicola, J.C. \& Bergqvist, L.P. 2009. A new cingulate (Mammalia: Xenarthra), Pachyarmatherium brasiliense sp. nov., from the Late Pleistocene of Northeastern Brazil. Journal of Vertebrate Paleontology, 29:881-893. doi:10.1671/039.029.0305

Porpino, K.O.; Fernicola, J.C.; Cruz, L.E. \& Bergqvist, L.P. 2014. The intertropical Brazilian species of Panochthus (Xenarthra, Cingulata, Glyptodontoidea): a reappraisal of their taxonomy and phylogenetic affinities. Journal of Vertebrate Paleontology, 34:1165-1179. doi:10.1080/02724634.2014.863203

Wible J.R \& Gaudin. T. 2006. The phylogeny of living and extinct armadillos (Mammalia, Xenarthra, Cingulata): a craniodental analysis. Amniote Paleobiology: Perspectives on the Evolution of Mammals, Birds, and Reptiles, University of Chicago Press, Chicago, IL, 153-198.

Wolf, D. 2007. Osteoderm histology of extinct and recent Cingulata and Phyllophaga (Xenarthra, Mammalia): implications for systematics and biomechanical adaptation. Hallesches Jahrbuch für Geowissenschaften Beiheft, 23:145-151.

Wolf, D.; Kalthoff, D.C. \& Sander, P.M. 2012. Osteoderm histology of the Pampatheriidae (Cingulata, Xenarthra, Mammalia): implications for systematics, osteoderm growth, and biomechanical adaptation. Journal of Morphology, 273:388-404. doi:10.1002/jmor.11029

Zurita, A.E. \& Ferrero, B.S. 2009. Una nueva especie de Neuryurus Ameghino (Mammalia, Glyptodontidae) en el Pleistoceno tardío de la Mesopotamia de Argentina. Geobios, 42:663-673. doi:10.1016/j.geobios.2009.03.003

Zurita, A.E.; González-Ruiz, L.; Gómez-Cruz, A.; Arenas- Mosquera, J.E. 2013. The most complete known Neogene Glyptodontidae (Mammalia, Xenarthra, Cingulata) from northern South America: taxonomic, paleobiogeographic and phylogenetic implications. Journal of Vertebrate Paleontology, 33:696-708. doi:10.1080/02724634.2013.726677

Zurita, A.E.; Soibelzon, E. \& Carlini, A.A. 2006. Neuryurus (Xenarthra, Glyptodontidae) in the Lujanian (late Pleistoceneearly Holocene) of the Pampean region. Neues Jahrbuch für Geologie und Paläontologie, Monatshefte, 2:78-88.

Received in 05 November, 2017; Accepted in 30 April, 2018. 